\title{
A Review on Heavy Metals (As, Pb, and Hg) Uptake by Plants through Phytoremediation
}

\author{
Bieby Voijant Tangahu, ${ }^{1}$ Siti Rozaimah Sheikh Abdullah, ${ }^{2}$ Hassan Basri, ${ }^{1}$ \\ Mushrifah Idris, ${ }^{3}$ Nurina Anuar, ${ }^{2}$ and Muhammad Mukhlisin ${ }^{1}$ \\ ${ }^{1}$ Department of Civil and Structural Engineering, Faculty of Engineering and Built Environment, \\ Universiti Kebangsaan Malaysia, 43600 Bangin, Malaysia \\ ${ }^{2}$ Department of Chemical Engineering, Faculty of Engineering and Built Environment, Universiti Kebangsaan Malaysia, \\ 43600 Bangin, Malaysia \\ ${ }^{3}$ Tasik Chini Reasearch Centre, Faculty of Science and Technology, Universiti Kebangsaan Malaysia, 43600 Bangin, Malaysia
}

Correspondence should be addressed to Bieby Voijant Tangahu, voijant@its.ac.id

Received 17 March 2011; Accepted 3 June 2011

Academic Editor: Hans-Jörg Bart

Copyright (C) 2011 Bieby Voijant Tangahu et al. This is an open access article distributed under the Creative Commons Attribution License, which permits unrestricted use, distribution, and reproduction in any medium, provided the original work is properly cited.

\begin{abstract}
Heavy metals are among the most important sorts of contaminant in the environment. Several methods already used to clean up the environment from these kinds of contaminants, but most of them are costly and difficult to get optimum results. Currently, phytoremediation is an effective and affordable technological solution used to extract or remove inactive metals and metal pollutants from contaminated soil and water. This technology is environmental friendly and potentially cost effective. This paper aims to compile some information about heavy metals of arsenic, lead, and mercury (As, $\mathrm{Pb}$, and $\mathrm{Hg}$ ) sources, effects and their treatment. It also reviews deeply about phytoremediation technology, including the heavy metal uptake mechanisms and several research studies associated about the topics. Additionally, it describes several sources and the effects of $\mathrm{As}$, $\mathrm{Pb}$, and $\mathrm{Hg}$ on the environment, the advantages of this kind of technology for reducing them, and also heavy metal uptake mechanisms in phytoremediation technology as well as the factors affecting the uptake mechanisms. Some recommended plants which are commonly used in phytoremediation and their capability to reduce the contaminant are also reported.
\end{abstract}

\section{Introduction}

Heavy metals are among the contaminants in the environment. Beside the natural activities, almost all human activities also have potential contribution to produce heavy metals as side effects. Migration of these contaminants into noncontaminated areas as dust or leachates through the soil and spreading of heavy metals containing sewage sludge are a few examples of events contributing towards contamination of the ecosystems [1].

Several methods are already being used to clean up the environment from these kinds of contaminants, but most of them are costly and far away from their optimum performance. The chemical technologies generate large volumetric sludge and increase the costs [2]; chemical and thermal methods are both technically difficult and expensive that all of these methods can also degrade the valuable component of soils [3]. Conventionally, remediation of heavy-metalcontaminated soils involves either onsite management or excavation and subsequent disposal to a landfill site. This method of disposal solely shifts the contamination problem elsewhere along with the hazards associated with transportation of contaminated soil and migration of contaminants from landfill into an adjacent environment. Soil washing for removing contaminated soil is an alternative way to excavation and disposal to landfill. This method is very costy and produces a residue rich in heavy metals, which will require further treatment. Moreover, these physio-chemical technologies used for soil remediation render the land usage as a medium for plant growth, as they remove all biological activities [1].

Recent concerns regarding the environmental contamination have initiated the development of appropriate technologies to assess the presence and mobility of metals in 
soil [4], water, and wastewater. Presently, phytoremediation has become an effective and affordable technological solution used to extract or remove inactive metals and metal pollutants from contaminated soil. Phytoremediation is the use of plants to clean up a contamination from soils, sediments, and water. This technology is environmental friendly and potentially costeffective. Plants with exceptional metal-accumulating capacity are known as hyperaccumulator plants [5]. Phytoremediation takes the advantage of the unique and selective uptake capabilities of plant root systems, together with the translocation, bioaccumulation, and contaminant degradation abilities of the entire plant body [3].

Many species of plants have been successful in absorbing contaminants such as lead, cadmium, chromium, arsenic, and various radionuclides from soils. One of phytoremediation categories, phytoextraction, can be used to remove heavy metals from soil using its ability to uptake metals which are essential for plant growth (Fe, Mn, Zn, Cu, Mg, Mo, and Ni). Some metals with unknown biological function $(\mathrm{Cd}, \mathrm{Cr}, \mathrm{Pb}$, $\mathrm{Co}, \mathrm{Ag}, \mathrm{Se}, \mathrm{Hg}$ ) can also be accumulated [5].

The objectives of this paper are to discuss the potential of phytoremediation technique on treating heavy metalcontaminated side, to provide a brief view about heavy metals uptake mechanisms by plant, to give some description about the performance of several types of plants to uptake heavy metals and to describe about the fate of heavy metals in plant tissue, especially on arsenic (As), lead $(\mathrm{Pb})$, and mercury $(\mathrm{Hg})$. This study is related to a research project that aims to identify potential plants in tropical country such as Malaysia which can uptake heavy metal contaminants from petrochemical wastewater.

\section{Heavy Metals: Sources and Effect in the Environment}

Heavy metals are conventionally defined as elements with metallic properties and an atomic number $>20$. The most common heavy metal contaminants are $\mathrm{Cd}, \mathrm{Cr}, \mathrm{Cu}, \mathrm{Hg}, \mathrm{Pb}$, and $\mathrm{Zn}$. Metals are natural components in soil [6]. Some of these metals are micronutrients necessary for plant growth, such as $\mathrm{Zn}, \mathrm{Cu}, \mathrm{Mn}, \mathrm{Ni}$, and $\mathrm{Co}$, while others have unknown biological function, such as $\mathrm{Cd}, \mathrm{Pb}$, and $\mathrm{Hg}$ [1].

Metal pollution has harmful effect on biological systems and does not undergo biodegradation. Toxic heavy metals such as $\mathrm{Pb}, \mathrm{Co}, \mathrm{Cd}$ can be differentiated from other pollutants, since they cannot be biodegraded but can be accumulated in living organisms, thus causing various diseases and disorders even in relatively lower concentrations [7]. Heavy metals, with soil residence times of thousands of years, pose numerous health dangers to higher organisms. They are also known to have effect on plant growth, ground cover and have a negative impact on soil microflora [8]. It is well known that heavy metals cannot be chemically degraded and need to be physically removed or be transformed into nontoxic compounds [1].

2.1. Arsenic (As). Arsenic (atomic number 33) is a silver-grey brittle crystalline solid with atomic weight of 74.9, specific gravity 5.73 , melting point $817^{\circ} \mathrm{C}$ (at 28 atm), boiling point $613^{\circ} \mathrm{C}$, and vapor pressure $1 \mathrm{~mm} \mathrm{Hg}$ at $372^{\circ} \mathrm{C}$ [9]. Arsenic is a semimetallic element with the chemical symbol "As". Arsenic is odorless and tasteless. Arsenic can combine with other elements to form inorganic and organic arsenicals [10]. In the environment, arsenic is combined with oxygen, chlorine, and sulfur to form inorganic arsenic compounds. Inorganic arsenic compounds are mainly used to preserve wood. Organic arsenic compounds are used as pesticides, primarily on cotton plants [11].

Arsenic exists in the $-3,0,+3$, and +5 valence oxidation states [9], and in a variety of chemical forms in natural waters and sediments [12]. Environmental forms include arsenious acids $\left(\mathrm{H}_{3} \mathrm{AsO}_{3}, \mathrm{H}_{3} \mathrm{AsO}_{3}, \mathrm{H}_{3} \mathrm{AsO}_{3}{ }^{2-}\right)$, arsenic acids $\left(\mathrm{H}_{3} \mathrm{AsO}_{4}\right.$, $\mathrm{H}_{3} \mathrm{AsO}_{4}{ }^{-}, \mathrm{H}_{3} \mathrm{AsO}_{4}{ }^{2-}$ ), arsenites, arsenates, methylarsenic acid, dimethylarsinic acid, and arsine. Two most common forms in natural waters arsenite $\left(\mathrm{AsO}_{3}{ }^{3-}\right)$ and inorganic arsenate $\left(\mathrm{AsO}_{4}{ }^{3-}\right)$, referred as $\mathrm{As}^{3+}$ and $\mathrm{As}^{5+}$ [9]. From both the biological and the toxicological points of view, arsenic compounds can be classified into three major groups. These groups are inorganic arsenic compounds, organic arsenic compounds, and arsine gas [13].

It is a hard acid and preferentially complexes with oxides and nitrogen. Trivalent arsenites predominate in moderately reducing anaerobic environments such as groundwater [9]. The most common trivalent inorganic arsenic compounds are arsenic trioxide, sodium arsenite, and arsenic trichloride [13]. Trivalent $(+3)$ arsenates include $\mathrm{As}(\mathrm{OH})_{3}, \mathrm{As}(\mathrm{OH})_{4}{ }^{-}$, $\mathrm{AsO}_{2} \mathrm{OH}^{2-}$, and $\mathrm{AsO}_{3}{ }^{3-}$ [9]. Arsenite $\left(\mathrm{As}(\mathrm{OH})_{3}, \mathrm{As}^{3+}\right)$ is predominant in reduced redox potential conditions [12].

Arsenic is one of the contaminants found in the environment which is notoriously toxic to man and other living organisms [14]. It is a highly toxic element that exists in various species, and the toxicity of arsenic depends on its species. The $\mathrm{pH}$, redox conditions, surrounding mineral composition, and microbial activities affect the form (inorganic or organic) and the oxidation state of arsenic. It is generally accepted that the inorganic species, arsenite $\left[\mathrm{As}^{3+}\right]$ and arsenate $\left[\mathrm{As}^{5+}\right]$, are the predominant species in most environments, although the organic ones might also be present [15].

In general, inorganic compounds of arsenic are regarded as more highly toxic than most organic forms which are less toxic $[10,14,16,17]$. The trivalent compounds (arsenites) are more toxic than the pentavalent compounds (arsenates) $[16,17]$. It has been reported that $\mathrm{As}^{3+}$ is 4 to 10 times more soluble in water than $\mathrm{As}^{5+}$. However, the trivalent methylated arsenic species have been found to be more toxic than inorganic arsenic because they are more efficient at causing DNA breakdown [17]. Although $\mathrm{As}^{5+}$ tends to be less toxic compared to of $\mathrm{As}^{3+}$, it is thermodynamically more stable due to it predominates under normal conditions and becomes the cause of major contaminant in ground water [14]. Arsenate which is in the pentavalent state $\left(\mathrm{As}^{5+}\right)$ is also considered to be toxic and carcinogenic to human [18].

2.2. Lead $(\mathrm{Pb})$. Lead $(\mathrm{Pb})$, with atomic number 82 , atomic weight 207.19, and a specific gravity of 11.34 , is a bluish or silvery-grey metal with a melting point of $327.5^{\circ} \mathrm{C}$ and a 
boiling point at atmospheric pressure of $1740^{\circ} \mathrm{C}$. It has four naturally occurring isotopes with atomic weights 208, 206, 207 and 204 (in decreasing order of abundance). Despite the fact that lead has four electrons on its valence shell, its typical oxidation state is +2 rather than +4 , since only two of the four electrons ionize easily. Apart from nitrate, chlorate, and chloride, most of the inorganic salts of lead ${ }^{2+}$ have poor solubility in water [19]. Lead ( $\mathrm{Pb})$ exists in many forms in the natural sources throughout the world and is now one of the most widely and evenly distributed trace metals. Soil and plants can be contaminated by lead from car exhaust, dust, and gases from various industrial sources.

$\mathrm{Pb}^{2+}$ was found to be acute toxic to human beings when present in high amounts. Since $\mathrm{Pb}^{2+}$ is not biodegradable, once soil has become contaminated, it remains a long-term source of $\mathrm{Pb}^{2+}$ exposure. Metal pollution has a harmful effect on biological systems and does not undergo biodegradation [7].

Soil can be contaminated with $\mathrm{Pb}$ from several other sources such as industrial sites, from leaded fuels, old lead plumbing pipes, or even old orchard sites in production where lead arsenate is used. Lead accumulates in the upper 8 inches of the soil and is highly immobile. Contamination is long-term. Without remedial action, high soil lead levels will never return to normal [20].

In the environment, lead is known to be toxic to plants, animals, and microorganisms. Effects are generally limited to especially contaminated areas [21]. $\mathrm{Pb}$ contamination in the environment exists as an insoluble form, and the toxic metals pose serious human health problem, namely, brain damage and retardation [5].

2.3. Mercury $(\mathrm{Hg})$. Mercury is a naturally occurring metal that is present in several forms. Metallic mercury is shiny, silver-white, odorless liquid. Mercury combines with other elements, such as chlorine, sulfur, or oxygen, to form inorganic mercury compounds or salts, which are usually white powders or crystals. Mercury also combines with carbon to make organic mercury compounds [22]. Mercury, which has the lowest melting point $\left(-39^{\circ} \mathrm{C}\right)$ of all the pure metals, is the only pure metal that is liquid at room temperature. However, due to its several physical and chemical advantages such as its low boiling point $\left(357^{\circ} \mathrm{C}\right)$ and easy vaporization, mercury is still an important material in many industrial products [23]. As any other metal, mercury could occur in the soil in various forms. It dissolves as free ion or soluble complex and is nonspecifically adsorbed by binding mainly due to the electrostatic forces, chelated, and precipitated as sulphide, carbonate, hydroxide, and phosphate. There are three soluble forms of $\mathrm{Hg}$ in the soil environment. The most reduced is $\mathrm{Hg}^{0}$ metal with the other two forms being ionic of mercurous ion $\mathrm{Hg}_{2}{ }^{2+}$ and mercuric ion $\mathrm{Hg}^{2+}$, in oxidizing conditions especially at low $\mathrm{pH}$. $\mathrm{Hg}^{+}$ion is not stable under environmental conditions since it dismutates into $\mathrm{Hg}^{0}$ and $\mathrm{Hg}^{2+}$. A second potential route for the conversion of mercury in the soil is methylation to methyl or dimethyl mercury by anaerobic bacteria [24].

Mercury is a persistent environmental pollutant with bioaccumulation ability in fish, animals, and human beings
[23]. Mercury salts and organomercury compounds are among the most poisonous substances in our environment. The mechanism and extent of toxicity depend strongly on the type of compound and the redox state of mercury [25].

Environmental contamination due to mercury is caused by several industries, petrochemicals, minings, painting, and also by agricultural sources such as fertilizer and fungicidal sprays [26]. Some of the more common sources of mercury found throughout the environment include but may not be limited to the household bleach, acid, and caustic chemicals (e.g., battery acid, household lye, muriatic acid (hydrochloric acid), sodium hydroxide, and sulfuric acid), instrumentation containing mercury (e.g., medical instruments, thermometers, barometers, and manometers), dental amalgam (fillings), latex paint (manufactured prior to 1990), batteries, electric lighting (fluorescent lamps, incandescent wire filaments, mercury vapor lamps, ultraviolet lamps), pesticides, pharmaceuticals (e.g., nasal sprays, cosmetics, contact lens products), household detergents and cleaners, laboratory chemicals, inks and paper coatings, lubrication oils, wiring devices and switches, and textiles. Though mercury use in many of the above items being produced now is restricted or banned, there are still some existing, older products in use [22].

Terrestrial plants are generally insensitive to the harmful effects of mercury compounds; however, mercury is known to affect photosynthesis and oxidative metabolism by interfering with electron transport in chloroplasts and mitochondria. Mercury also inhibits the activity of aquaporins and reduces plant water uptake [27].

Mercury and its compounds are cumulative toxins and in small quantities are hazardous to human health. The major effects of mercury poisoning manifest as neurological and renal disturbances as it can easily pass the blood-brain barrier and has effect on the brain [26].

\section{Phytoremediation Technology}

Phytoremediation techniques have been briefly depicted in many literatures or articles. The generic term "phytoremediation" consists of the Greek prefix phyto (plant), attached to the Latin root remedium (to correct or remove an evil) $[28,29]$. Some definitions on phytoremediation that have been described by several researchers are listed in Table 1.

Generally, according to the above researchers, phytoremediation is defined as an emerging technology using selected plants to clean up the contaminated environment from hazardous contaminant to improve the environment quality. Figure 1 depicts the uptake mechanisms of both organics and inorganics contaminants through phytoremediation technology. For organics, it involves phytostabilization, rhizodegradation, rhizofiltration, phytodegradation, and phytovolatilization. These mechanisms related to organic contaminant property are not able to be absorbed into the plant tissue. For inorganics, mechanisms which can be involved are phytostabilization, rhizofiltration, phytoaccumulation and phytovolatilization. 
TABLe 1: Definition of phytoremediation.

\begin{tabular}{|c|c|c|}
\hline No. & Researchers & Definition of phytoremediation \\
\hline (1) & {$[30]$} & The use of plants to improve degraded environments \\
\hline (2) & {$[31]$} & $\begin{array}{l}\text { The use of plants, including trees and grasses, to remove, destroy or sequester hazardous contaminants from } \\
\text { media such as air, water, and soil }\end{array}$ \\
\hline (3) & {$[24]$} & $\begin{array}{l}\text { The use of plants to remediate toxic chemicals found in contaminated soil, sludge, sediment, ground water, } \\
\text { surface water, and wastewater }\end{array}$ \\
\hline (4) & {$[32]$} & $\begin{array}{l}\text { An emerging technology using specially selected and engineered metal accumulating plants for } \\
\text { environmental cleanup }\end{array}$ \\
\hline (5) & {$[33]$} & The use of vascular plants to remove pollutants from the environment or to render them harmless \\
\hline (6) & {$[3]$} & $\begin{array}{l}\text { The engineered use of green plant to remove, contain, or render harmless such environmental contaminants } \\
\text { as heavy metals, trace elements, organic compounds, and radioactive compounds in soil or water. This } \\
\text { definition includes all plant-influenced biological, chemical, and physical processes that aid in the uptake, } \\
\text { sequestration, degradation, and metabolism of contaminants, either by plants or by the free-living organisms } \\
\text { that constitute the plant rhizosphere }\end{array}$ \\
\hline (7) & {$[29]$} & $\begin{array}{l}\text { Phytoremediation is the name given to a set of technologies that use different plants as a containment, } \\
\text { destruction, or an extraction technique. Phytoremediation is an emerging technology that uses various } \\
\text { plants to degrade, extract, contain, or immobilize contaminants from soil and water }\end{array}$ \\
\hline (8) & {$[34]$} & $\begin{array}{l}\text { Phytoremediation in general implies the use of plants (in combination with their associated } \\
\text { microorganisms) to remove, degrade, or stabilize contaminants }\end{array}$ \\
\hline
\end{tabular}

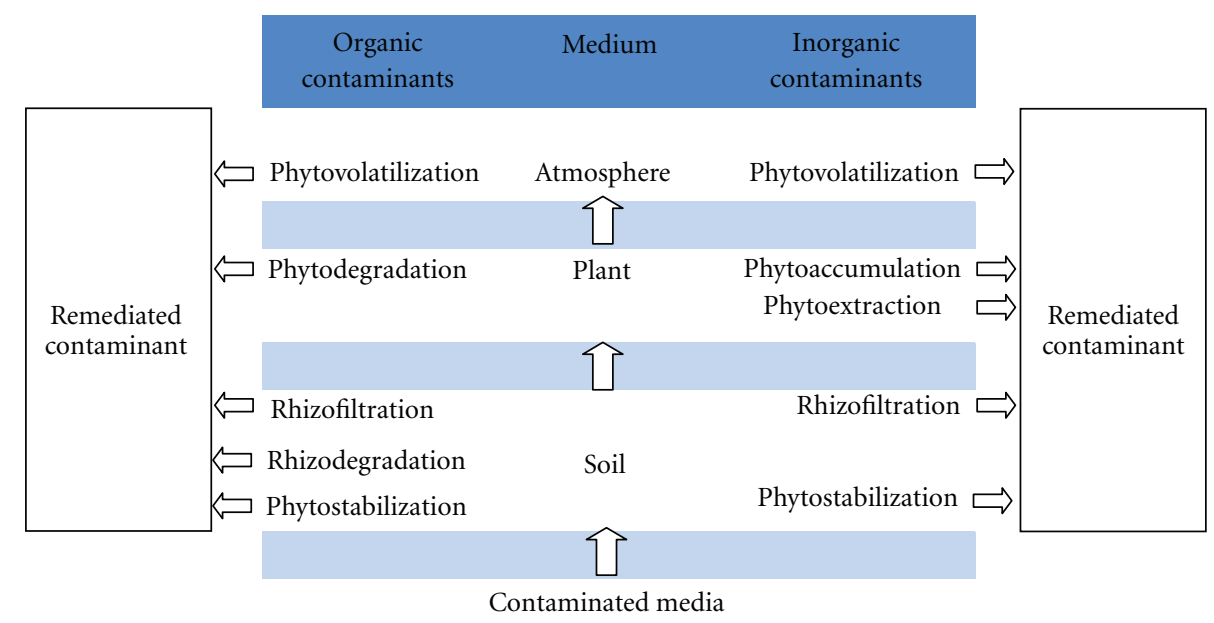

Figure 1: Uptake mechanisms on phytoremediation technology. Source: [35].

Based on Figure 1, some certain essential processes involved in phytoremediation technology $[29,31]$ are phytostabilization and phytoextraction for inorganic contaminants, and phytotransformation/phytodegradation, rhizofiltration, and rhizodegradation for organic contaminants.

The root plants exudates to stabilize, demobilize and bind the contaminants in the soil matrix, thereby reducing their bioavailability. These all are called as phytostabilization process. Certain plant species have used to immobilize contaminants in the soil and ground water through absorption and accumulation by roots, adsorption onto roots, or precipitation within the root zone. This process is for organics and metals contaminants in soils, sediments, and sludges medium [29, 31].

Specific plant species can absorb and hyperaccumulate metal contaminants and/or excess nutrients in harvestable root and shoot tissue, from the growth substrate through phytoextraction process. This is for metals, metalloids, radionuclides, nonmetals, and organics contaminants in soils, sediments, and sludges medium [29, 31].

Phytovolatilization process is the plants ability to absorb and subsequently volatilize the contaminant into the atmosphere. This process is for metal contaminants in groundwater, soils, sediments, and sludges medium. Since phytotransformation/phytodegradation process is the breakdown of contaminants taken up by plants through metabolic processes within the plant or the breakdown of contaminants externally to the plant through the effect of compounds produced by the plants. This process is for complex organic molecules that are degraded into simpler molecule contaminants in soils, sediments, sludges, and groundwater medium $[29,31]$.

Plant roots take up metal contaminants and/or excess nutrients from growth substrates through rhizofiltration 
(=root) process, the adsorption, or, precipitation onto plant roots or absorption into the roots of contaminants that are in solution surrounding the root zone. This process is for metals, excess nutrients, and radionuclide contaminants in groundwater, surface water, and wastewater medium [29, 31].

The breakdown of contaminants in the soil through microbial activity that is enhanced by the presence of the root zone is called rhizodegradation. This process uses microorganisms to consume and digest organic substances for nutrition and energy. Natural substances released by the plant roots, sugars, alcohols, and acids, contain organic carbon that provides food for soil microorganisms and establish a dense root mass that takes up large quantities of water. This process is for organic substance contaminants in soil medium $[29,31]$.

\section{Mechanisms of Heavy Metal Uptake by Plant}

Contaminant uptake by plants and its mechanisms have been being explored by several researchers. It could be used to optimize the factors to improve the performance of plant uptake. According to Sinha et al. [36], the plants act both as "accumulators" and "excluders". Accumulators survive despite concentrating contaminants in their aerial tissues. They biodegrade or biotransform the contaminants into inert forms in their tissues. The excluders restrict contaminant uptake into their biomass.

Plants have evolved highly specific and very efficient mechanisms to obtain essential micronutrients from the environment, even when present at low ppm levels. Plant roots, aided by plant-produced chelating agents and plantinduced $\mathrm{pH}$ changes and redox reactions, are able to solubilize and take up micronutrients from very low levels in the soil, even from nearly insoluble precipitates. Plants have also evolved highly specific mechanisms to translocate and store micronutrients. These same mechanisms are also involved in the uptake, translocation, and storage of toxic elements, whose chemical properties simulate those of essential elements. Thus, micronutrient uptake mechanisms are of great interest to phytoremediation [37].

The range of known transport mechanisms or specialized proteins embedded in the plant cell plasma membrane involved in ion uptake and translocation include (1) proton pumps (" -ATPases that consume energy and generate electrochemical gradients), (2) co- and antitransporters (proteins that use the electrochemical gradients generated by "-ATPases to drive the active uptake of ions), and (3) channels (proteins that facilitate the transport of ions into the cell). Each transport mechanism is likely to take up a range of ions. A basic problem is the interaction of ionic species during uptake of various heavy metal contaminants. After uptake by roots, translocation into shoots is desirable because the harvest of root biomass is generally not feasible. Little is known regarding the forms in which metal ions are transported from the roots to the shoots [37].

Plant uptake-translocation mechanisms are likely to be closely regulated. Plants generally do not accumulate trace elements beyond near-term metabolic needs. And these requirements are small ranging from 10 to $15 \mathrm{ppm}$ of most trace elements suffice for most needs [37]. The exceptions are "hyperaccumulator" plants, which can take up toxic metal ions at levels in the thousands of ppm. Another issue is the form in which toxic metal ions are stored in plants, particularly in hyperaccumulating plants, and how these plants avoid metal toxicity. Multiple mechanisms are involved. Storage in the vacuole appears to be a major one [37].

Water, evaporating from plant leaves, serves as a pump to absorb nutrients and other soil substances into plant roots. This process, termed evapotranspiration, is responsible for moving contamination into the plant shoots as well. Since contamination is translocated from roots to the shoots, which are harvested, contamination is removed while leaving the original soil undisturbed. Some plants that are used in phytoextraction strategies are termed "hyperaccumulators." They are plants that achieve a shoot-to-root metalconcentration ratio greater than one. Nonaccumulating plants typically have a shoot-to-root ratio considerably less than one. Ideally, hyperaccumulators should thrive in toxic environments, require little maintenance and produce high biomass, although few plants perfectly fulfill these requirements [38].

Metal accumulating plant species can concentrate heavy metals like $\mathrm{Cd}, \mathrm{Zn}, \mathrm{Co}, \mathrm{Mn}, \mathrm{Ni}$, and $\mathrm{Pb}$ up to 100 or 1000 times those taken up by nonaccumulator (excluder) plants. In most cases, microorganisms bacteria and fungi, living in the rhizosphere closely associated with plants, may contribute to mobilize metal ions, increasing the bioavailable fraction. Their role in eliminating organic contaminants is even more significant than that in case of inorganic compounds $[39,40]$.

Heavy metal uptake by plant through phytoremediation technologies is using these mechanisms of phytoextraction, phytostabilisation, rhizofiltration, and phytovolatilization as shown in Figure 2.

4.1. Phytoextraction. Phytoextraction is the uptake/absorption and translocation of contaminants by plant roots into the above ground portions of the plants (shoots) that can be harvested and burned gaining energy and recycling the metal from the ash $[28,39-42]$.

4.2. Phytostabilisation. Phytostabilisation is the use of certain plant species to immobilize the contaminants in the soil and groundwater through absorption and accumulation in plant tissues, adsorption onto roots, or precipitation within the root zone preventing their migration in soil, as well as their movement by erosion and deflation [28, 39-42].

4.3. Rhizofiltration. Rhizofiltration is the adsorption or precipitation onto plant roots or absorption into and sequesterization in the roots of contaminants that are in solution surrounding the root zone by constructed wetland for cleaning up communal wastewater [28, 39-42].

4.4. Phytovolatilization. Phytovolatilization is the uptake and transpiration of a contaminant by a plant, with release of the contaminant or a modified form of the contaminant to 


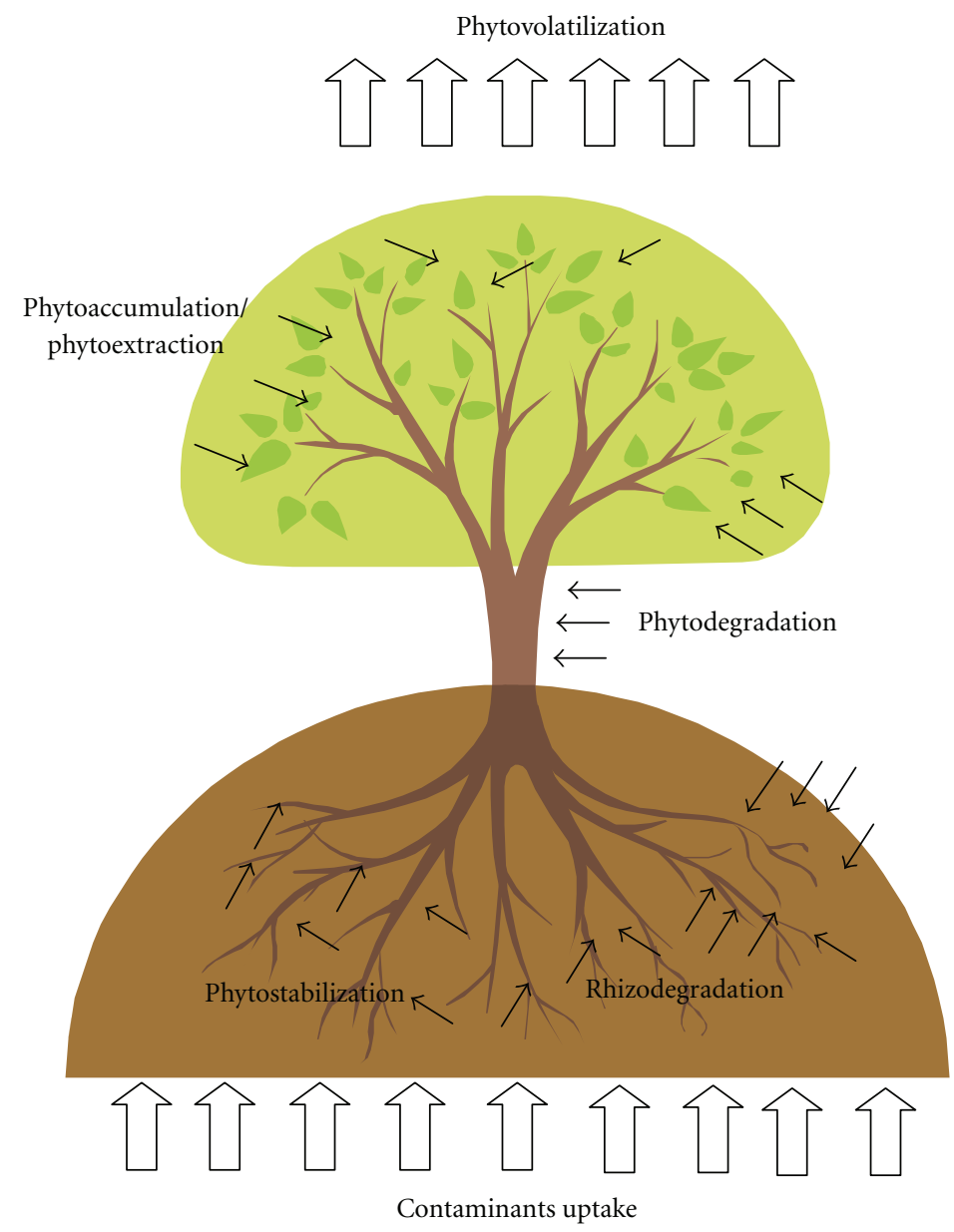

FIGURE 2: The mechanisms of heavy metals uptake by plant through phytoremediation technology.

the atmosphere from the plant. Phytovolatilization occurs as growing trees and other plants take up water along with the contaminants. Some of these contaminants can pass through the plants to the leaves and volatilize into the atmosphere at comparatively low concentrations [28, 39-42].

Plants also perform an important secondary role in physically stabilizing the soil with their root system, preventing erosion, protecting the soil surface, and reducing the impact of rain. At the same time, plant roots release nutrients that sustain a rich microbial community in the rhizosphere. Bacterial community composition in the rhizosphere is affected by complex interactions between soil type, plant species, and root zone location. Microbial populations are generally higher in the rhizosphere than in the root-free soil. This is due to a symbiotic relationship between soil microorganisms and plants. This symbiotic relationship can enhance some bioremediation processes. Plant roots also may provide surfaces for sorption or precipitation of metal contaminants [27].

In phytoremediation, the root zone is of special interest. The contaminants can be absorbed by the root to be subsequently stored or metabolised by the plant. Degradation of contaminants in the soil by plant enzymes exuded from the roots is another phytoremediation mechanism [43].
For many contaminants, passive uptake via micropores in the root cell walls may be a major route into the root, where degradation can take place [3].

\section{Factors Affecting the Uptake Mechanisms}

There are several factors which can affect the uptake mechanism of heavy metals, as shown in Figure 3. By having knowledge about these factors, the uptake performance by plant can be greatly improved.

5.1. The Plant Species. Plants species or varieties are screened, and those with superior remediation properties are selected [31]. The uptake of a compound is affected by plant species characteristic [44]. The success of the phytoextraction technique depends upon the identification of suitable plant species that hyperaccumulate heavy metals and produce large amounts of biomass using established crop production and management practices [24].

5.2. Properties of Medium. Agronomical practices are developed to enhance remediation ( $\mathrm{pH}$ adjustment, addition of chelators, fertilizers) [31]. For example, the amount of lead absorbed by plants is affected by the $\mathrm{pH}$, organic matter, and 


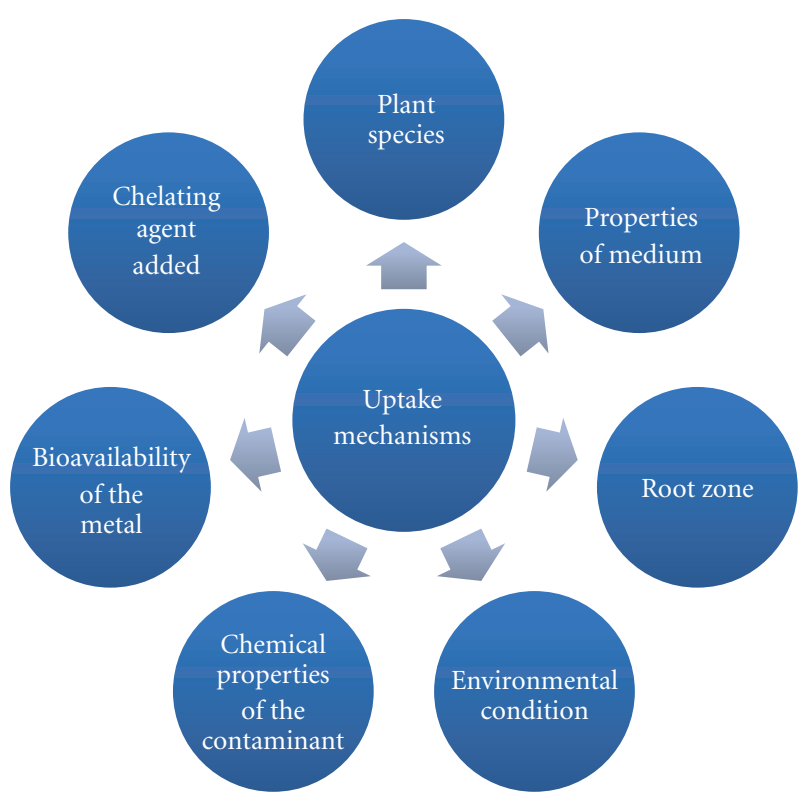

FIGURE 3: Factors which are affecting the uptake mechanisms of heavy metals.

the phosphorus content of the soil. To reduce lead uptake by plants, the $\mathrm{pH}$ of the soil is adjusted with lime to a level of 6.5 to $7.0[20]$.

5.3. The Root Zone. The Root Zone is of special interest in phytoremediation. It can absorb contaminants and store or metabolize it inside the plant tissue. Degradation of contaminants in the soil by plant enzymes exuded from the roots is another phytoremediation mechanism. A morphological adaptation to drought stress is an increase in root diameter and reduced root elongation as a response to less permeability of the dried soil [43].

5.4. Vegetative Uptake. Vegetative Uptake is affected by the environmental conditions [44]. The temperature affects growth substances and consequently root length. Root structure under field conditions differs from that under greenhouse condition [43]. The success of phytoremediation, more specifically phytoextraction, depends on a contaminant-specific hyperaccumulator [45]. Understanding mass balance analyses and the metabolic fate of pollutants in plants are the keys to proving the applicability of phytoremediation [46].

Metal uptake by plants depends on the bioavailability of the metal in the water phase, which in turn depends on the retention time of the metal, as well as the interaction with other elements and substances in the water. Furthermore, when metals have been bound to the soil, the $\mathrm{pH}$, redox potential, and organic matter content will all affect the tendency of the metal to exist in ionic and plant-available form. Plants will affect the soil through their ability to lower the $\mathrm{pH}$ and oxygenate the sediment, which affects the availability of the metals [47], increasing the bioavailability of heavy metals by the addition of biodegradable physicochemical factors, such as chelating agents and micronutrients [34].

5.5. Addition of Chelating Agent. The increase of the uptake of heavy metals by the energy crops can be influenced by increasing the bioavailability of heavy metals through addition of biodegradable physicochemical factors such as chelating agents, and micronutrients, and also by stimulating the heavy-metal-uptake capacity of the microbial community in and around the plant. This faster uptake of heavy metals will result in shorter and, therefore, less expensive remediation periods. However, with the use of synthetic chelating agents, the risk of increased leaching must be taken into account [34]. The use of chelating agents in heavy-metal-contaminated soils could promote leaching of the contaminants into the soil. Since the bioavailability of heavy metals in soils decreases above pH 5.5-6, the use of a chelating agent is warranted, and may be required, in alkaline soils. It was found that exposing plants to EDTA for a longer period ( 2 weeks) could improve metal translocation in plant tissue as well as the overall phytoextraction performance. The application of a synthetic chelating agent (EDTA) at $5 \mathrm{mmol} / \mathrm{kg}$ yielded positive results [8]. Plant roots exude organic acids such as citrate and oxalate, which affect the bioavailability of metals. In chelate-assisted phytoremediation, synthetic chelating agents such as NTA and EDTA are added to enhance the phytoextraction of soil-polluting heavy metals. The presence of a ligand affects the biouptake of heavy metals through the formation of metal-ligand complexes and changes the potential to leach metals below the root zone [48].

\section{Effectiveness of Heavy Metals Uptake by Plants}

Several studies have described the performance of heavy metals uptake by plants. It is reported that phytoremediation technology is an alternative to treat heavy-metalcontaminated side which will be more admitted in order to remediate the environment. Table 2 lists some research done to remediate heavy metals from contaminated soil, while Table 3 lists some research conducted to remediate them from contaminated water and wastewater.

Based on the collected data from the phytoremediation research listed in Tables 2 and 3, the accumulation of heavy metals $\mathrm{As}, \mathrm{Pb}$, and $\mathrm{Hg}$ in plant tissue is summarized in respective, Figures 4, 5, and 6 .

According to Figure 4, the highest accumulation of As in plant tissue (the researchers have not detailed which part it is, but it might be the whole plant) occurs in Pteris vittata L. species. It can reach more than $0.7 \mathrm{mg}$ As/g dry weight of plant. In plant root, the highest accumulation of As is in Populus nigra, which can reach more than $0.2 \mathrm{mg}$ As/g dry weight of plant root.

As can be seen in Figure 5, several plants could accumulate $\mathrm{Pb}$ in their tissue of more than $50 \mathrm{mg} / \mathrm{g}$ dry weight of plant. Among those species are species of Brassica campestris L, Brassica carinata A. Br., Brassica juncea (L.) Czern. and 


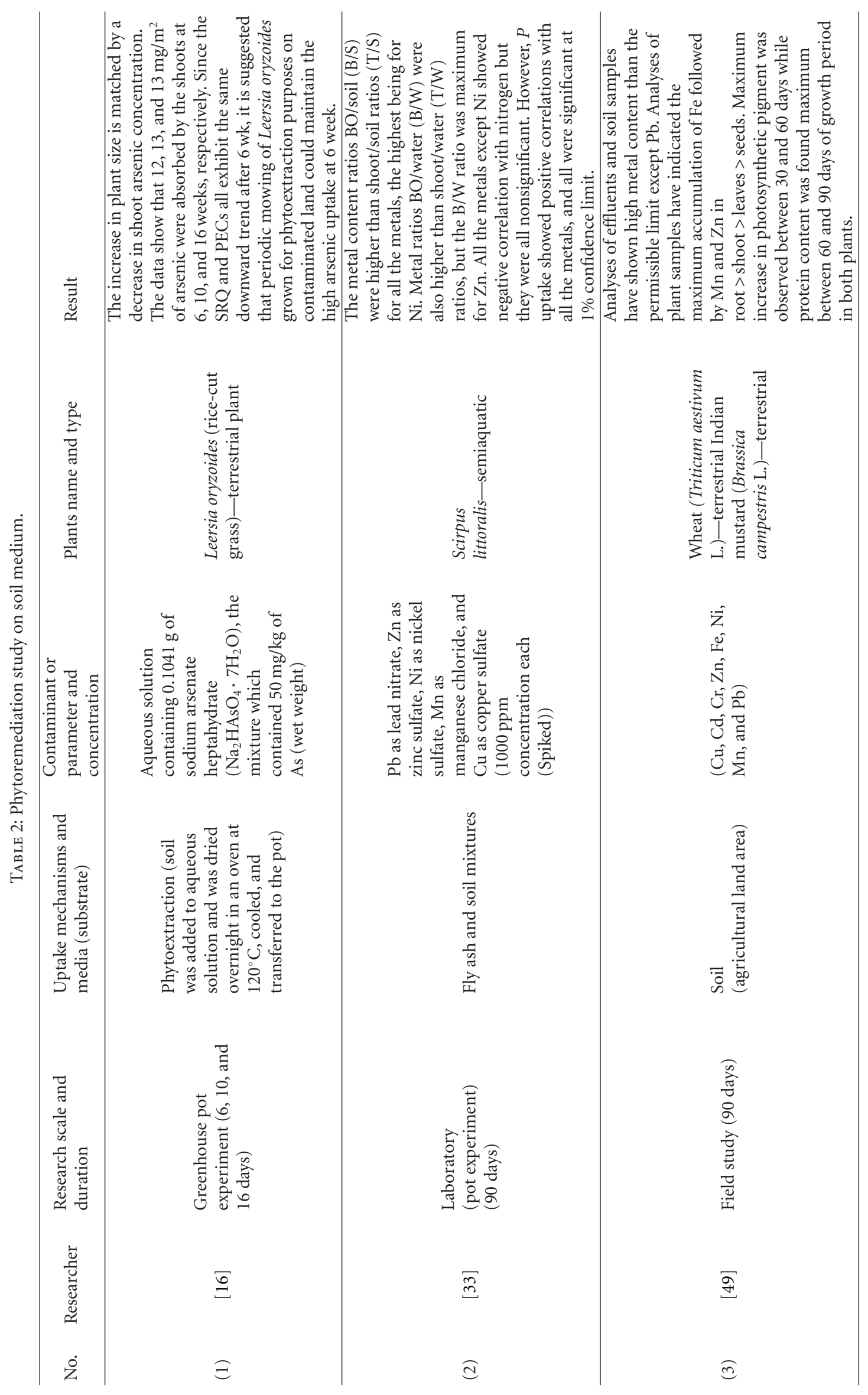




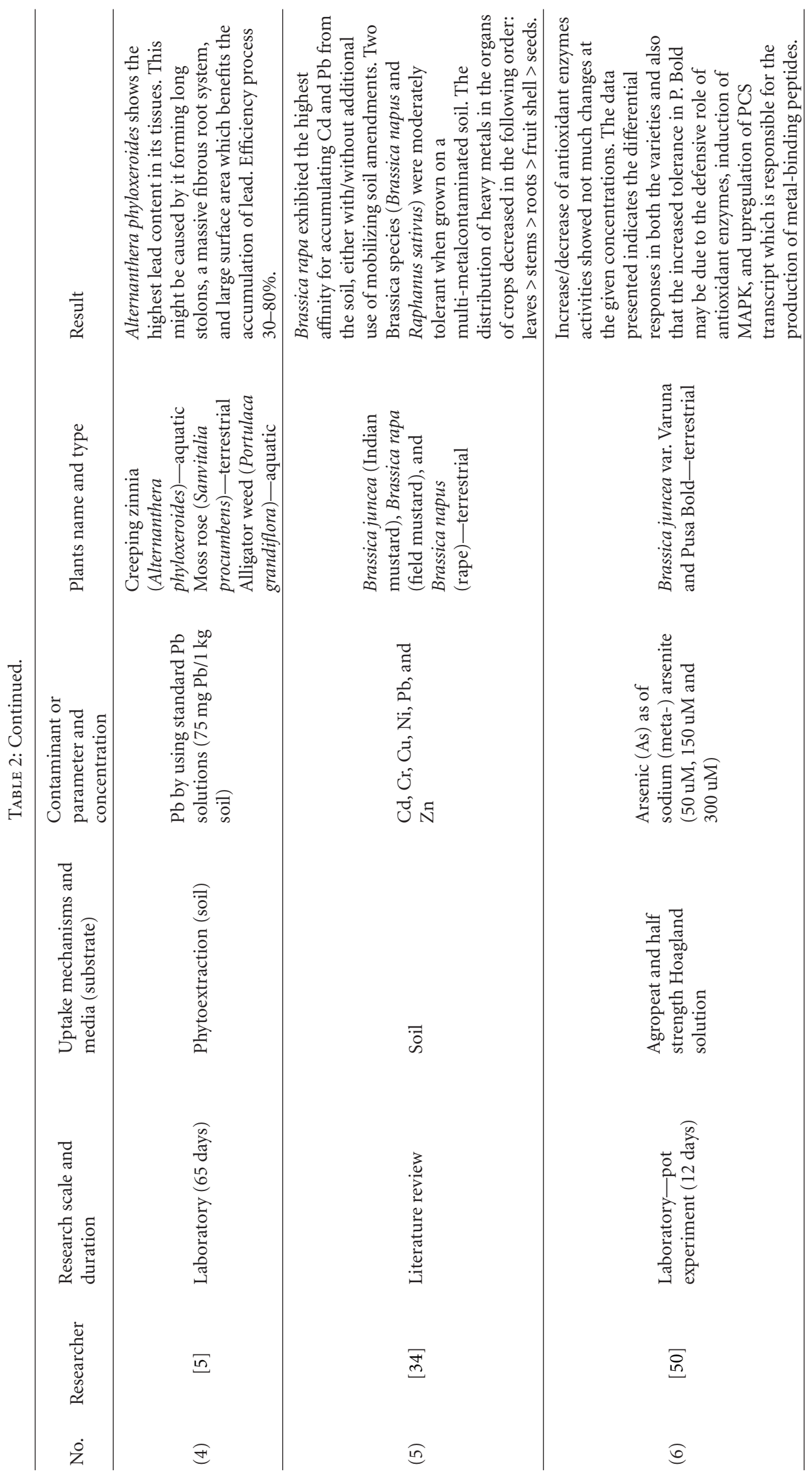




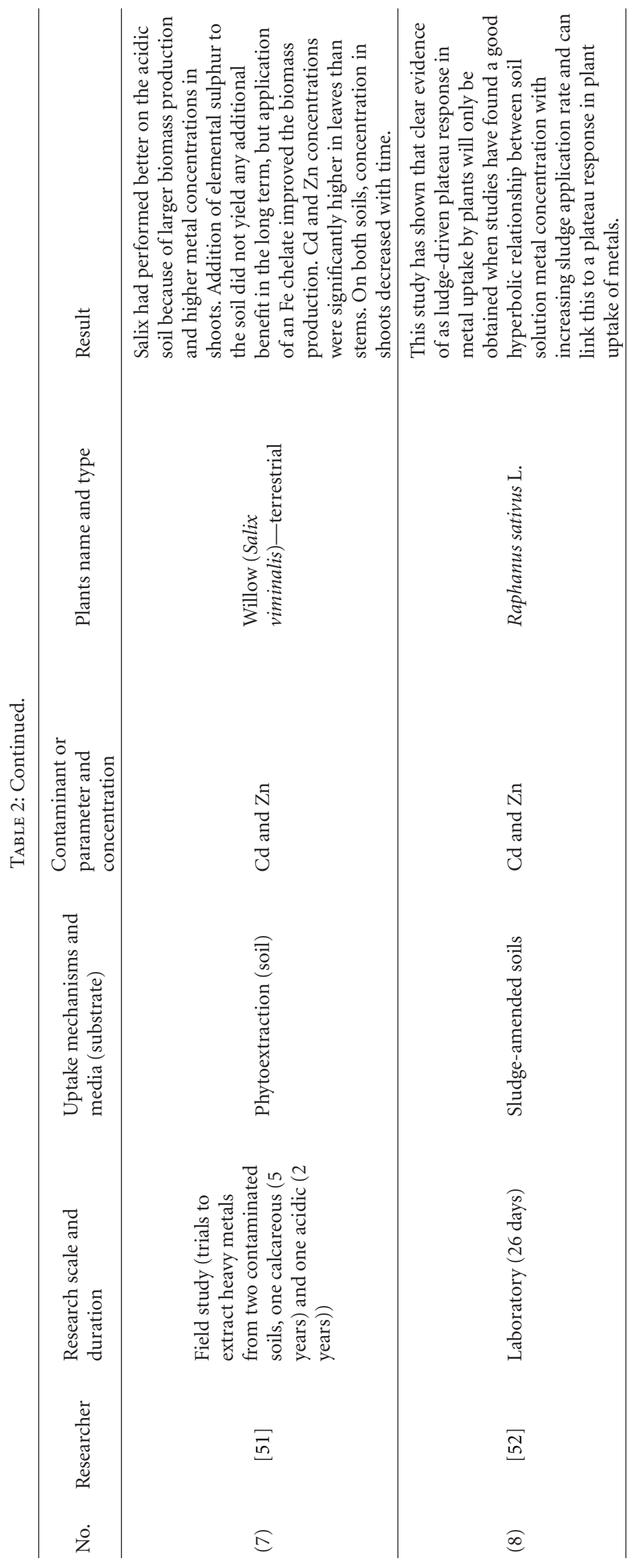




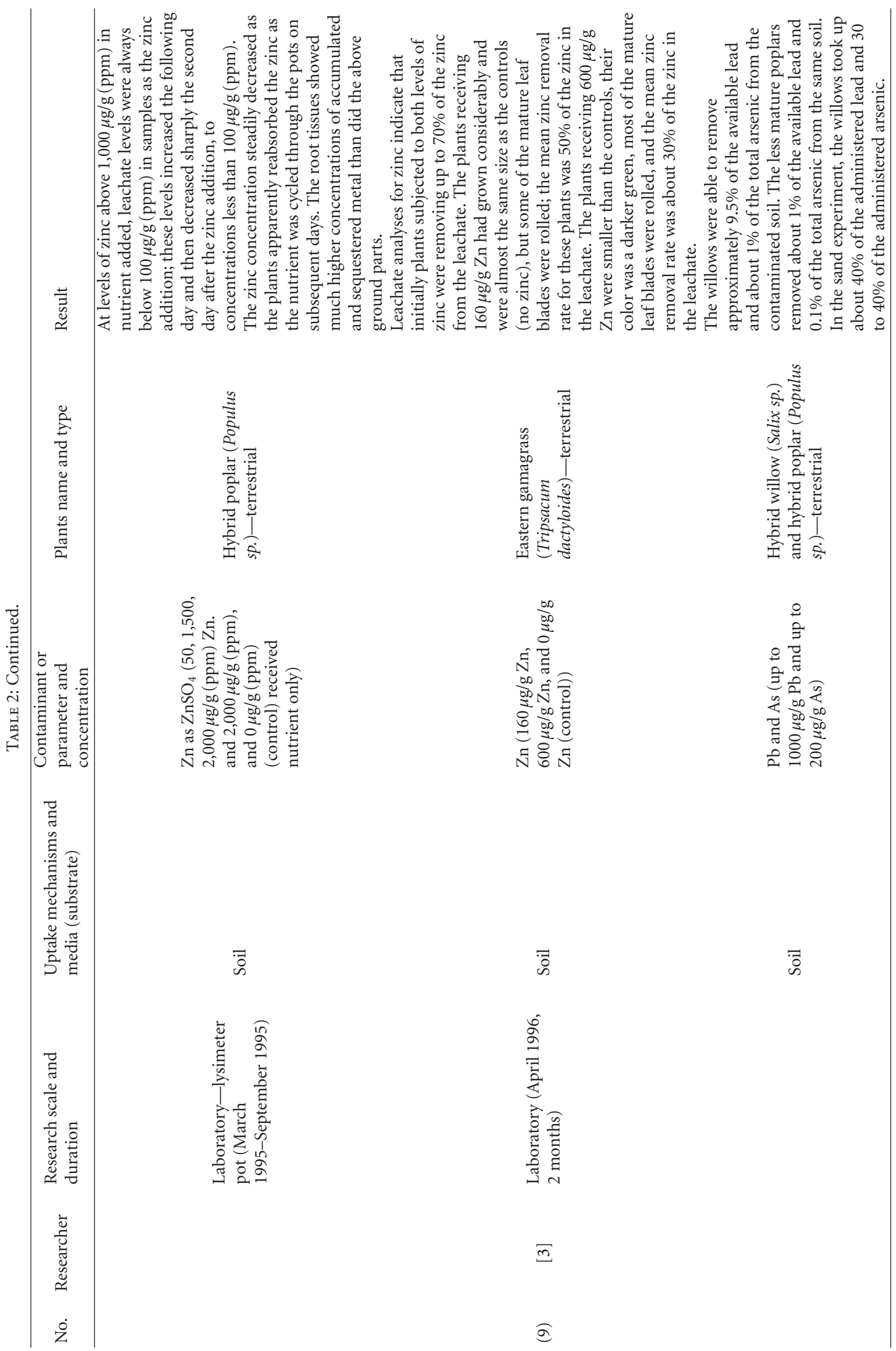




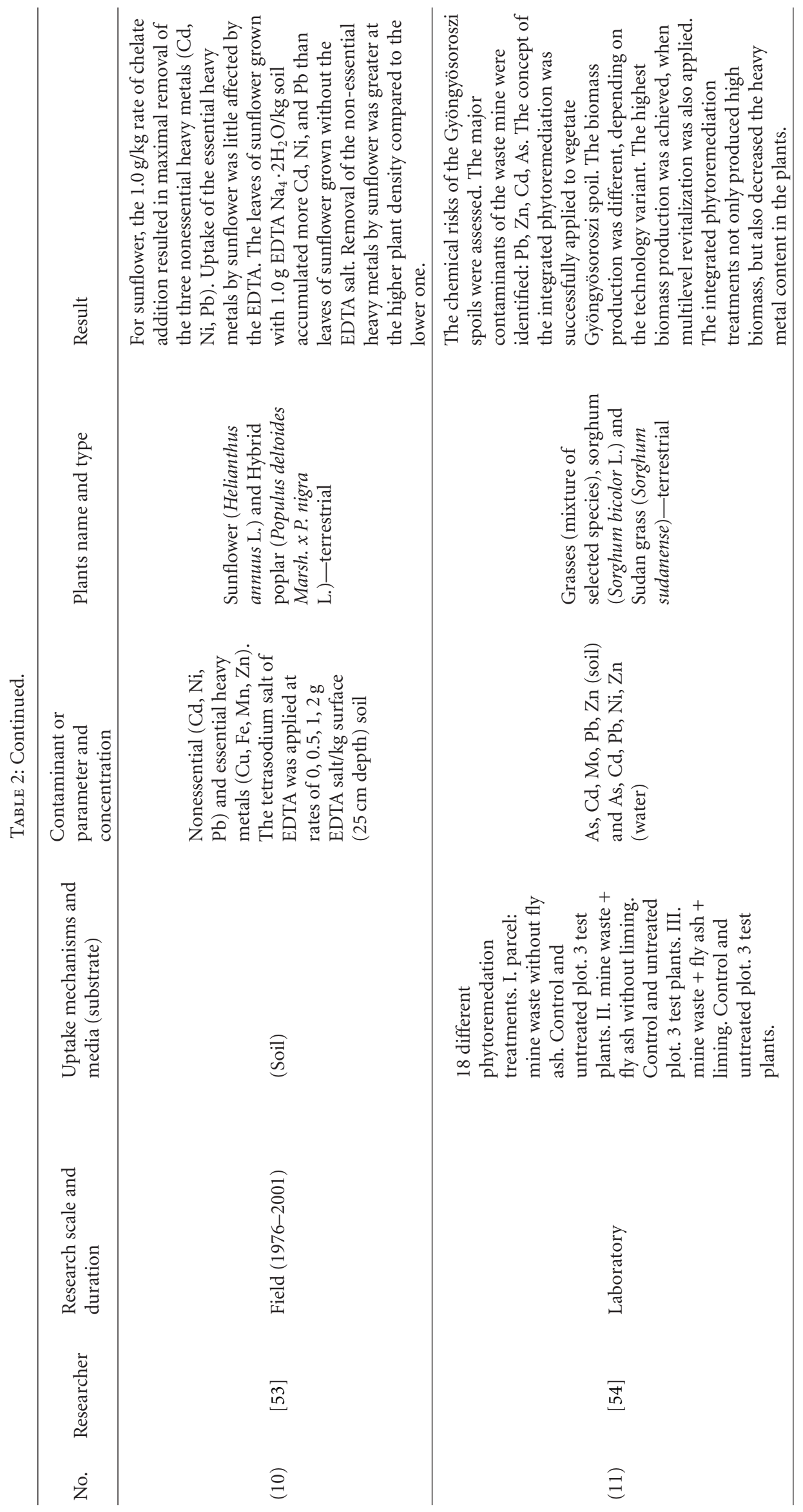




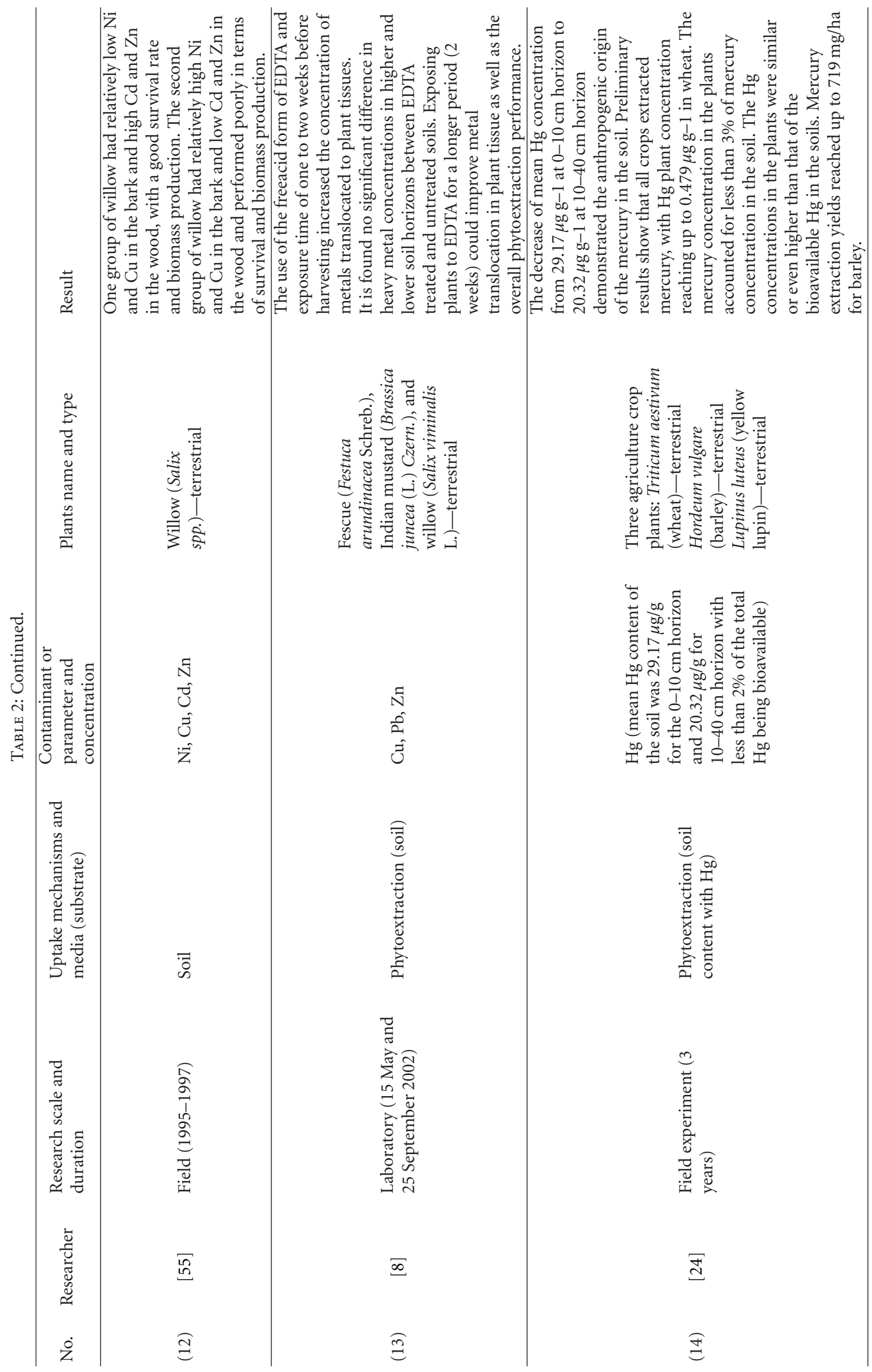




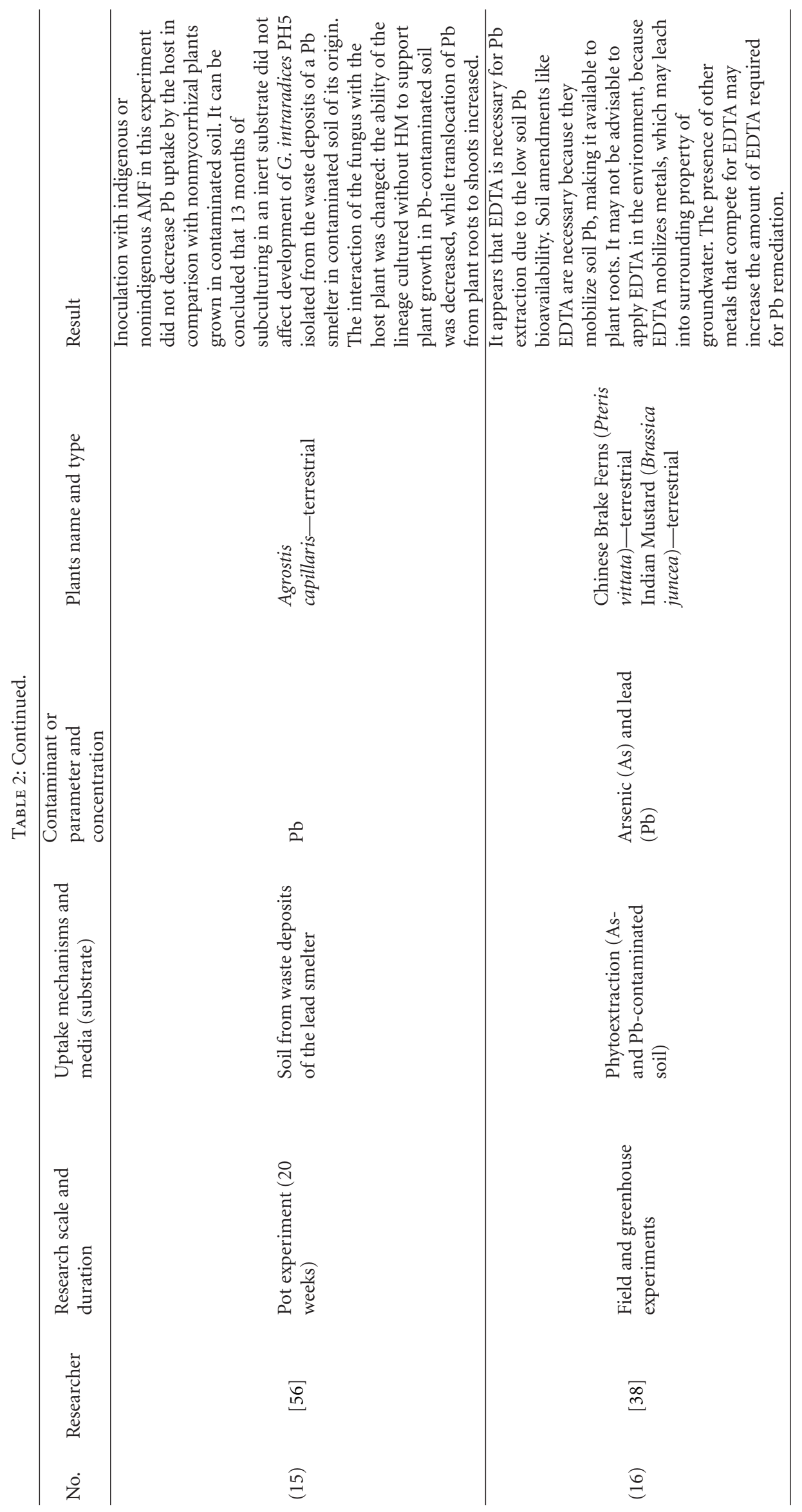




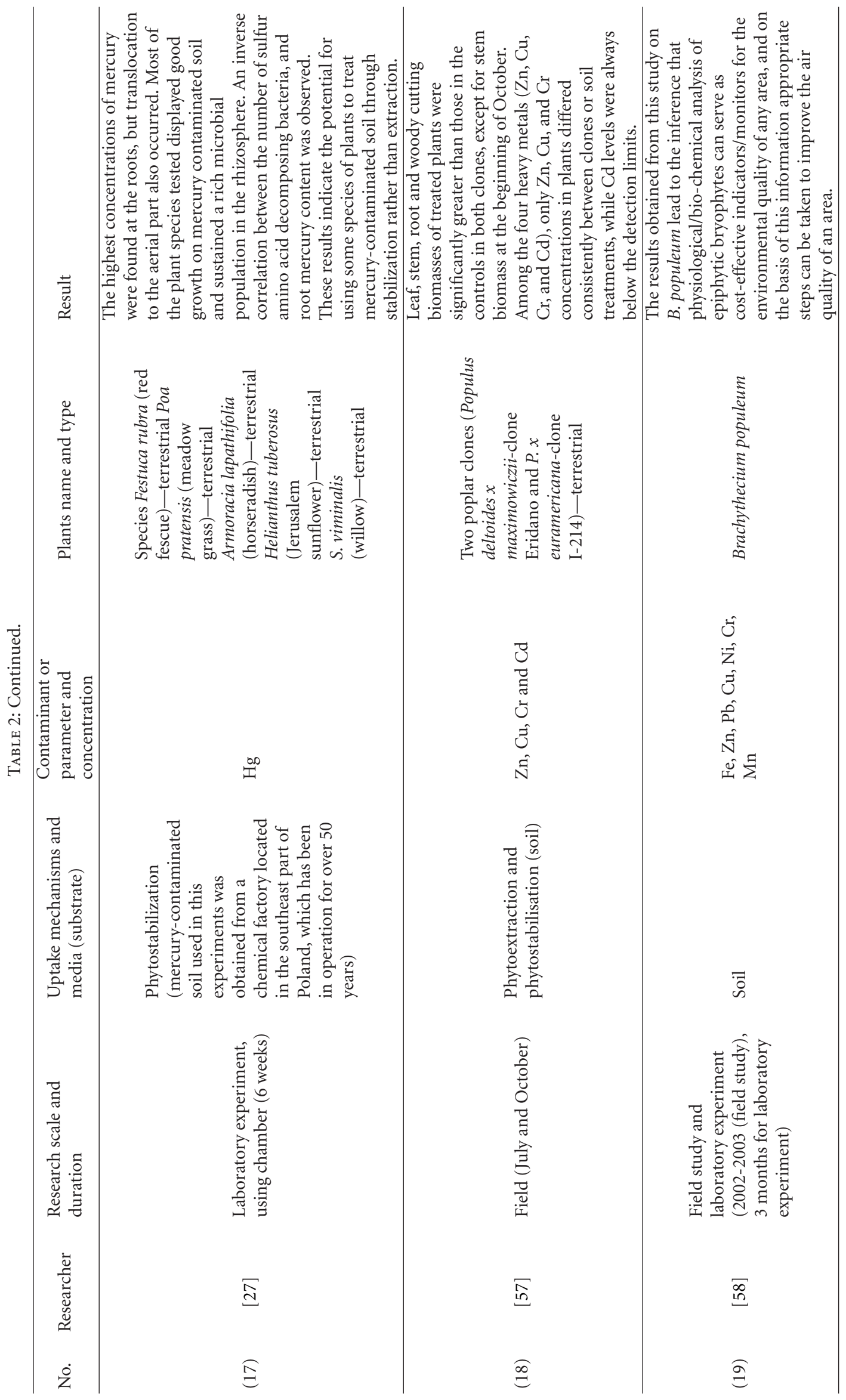




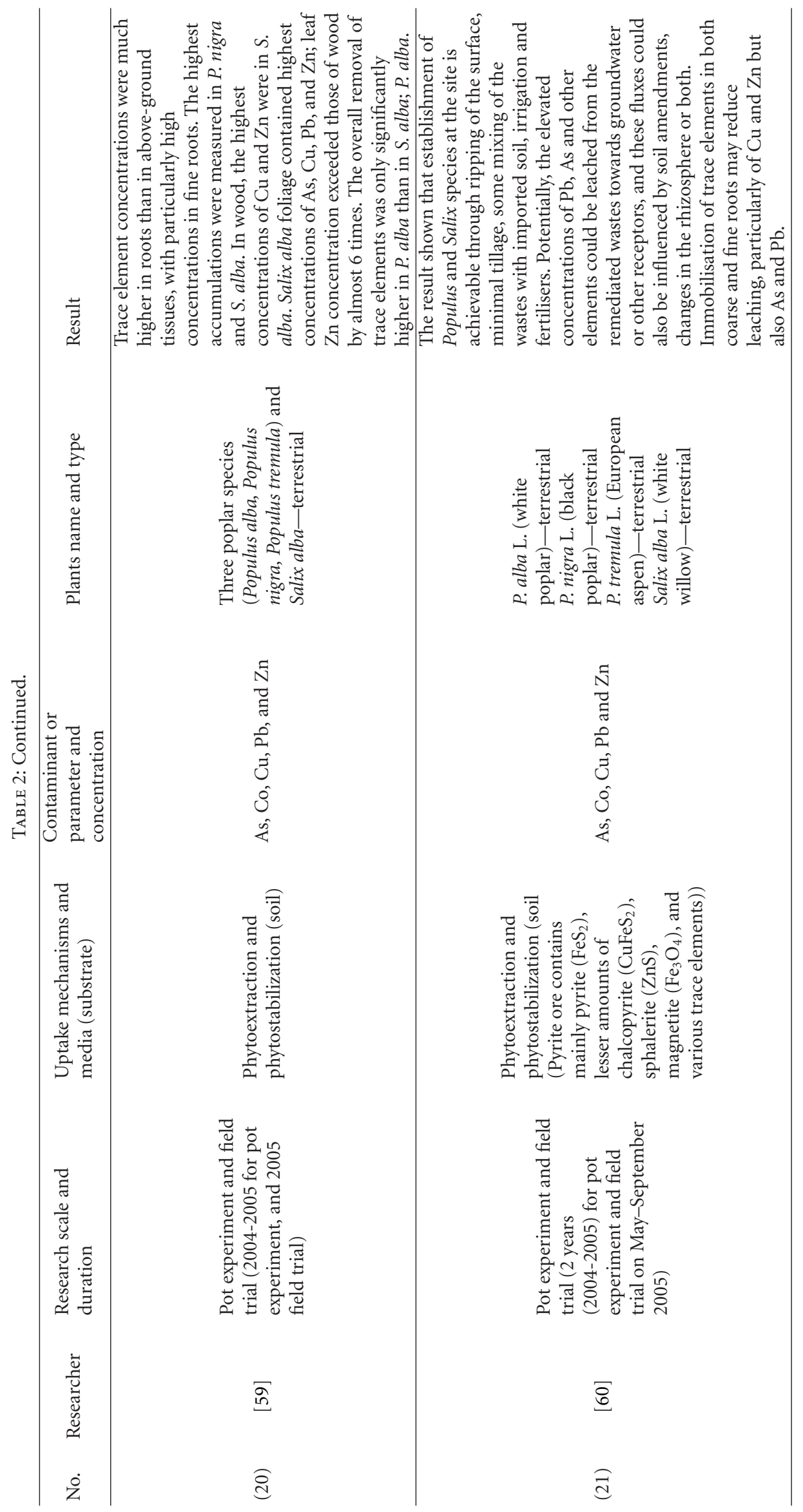




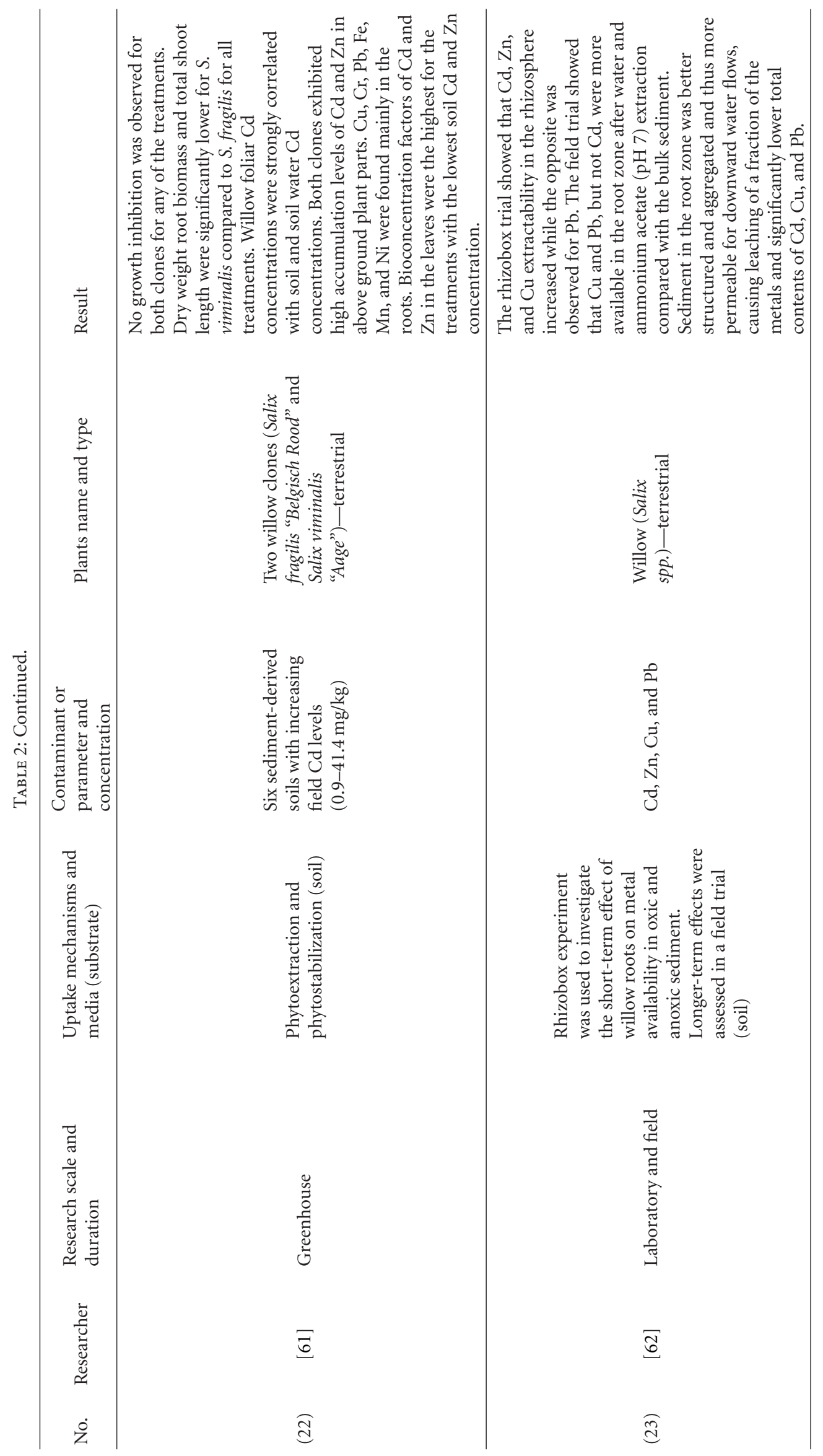




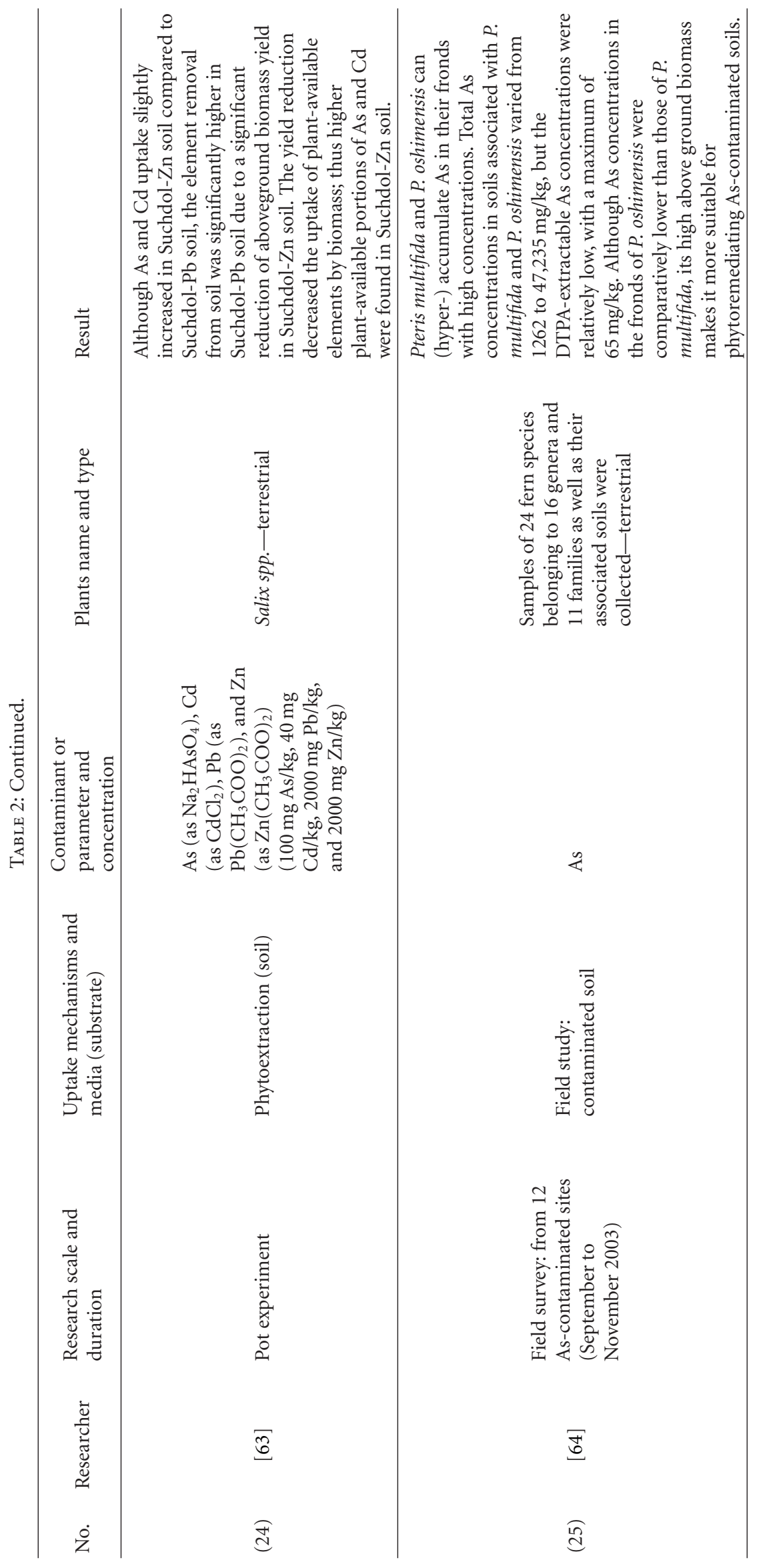




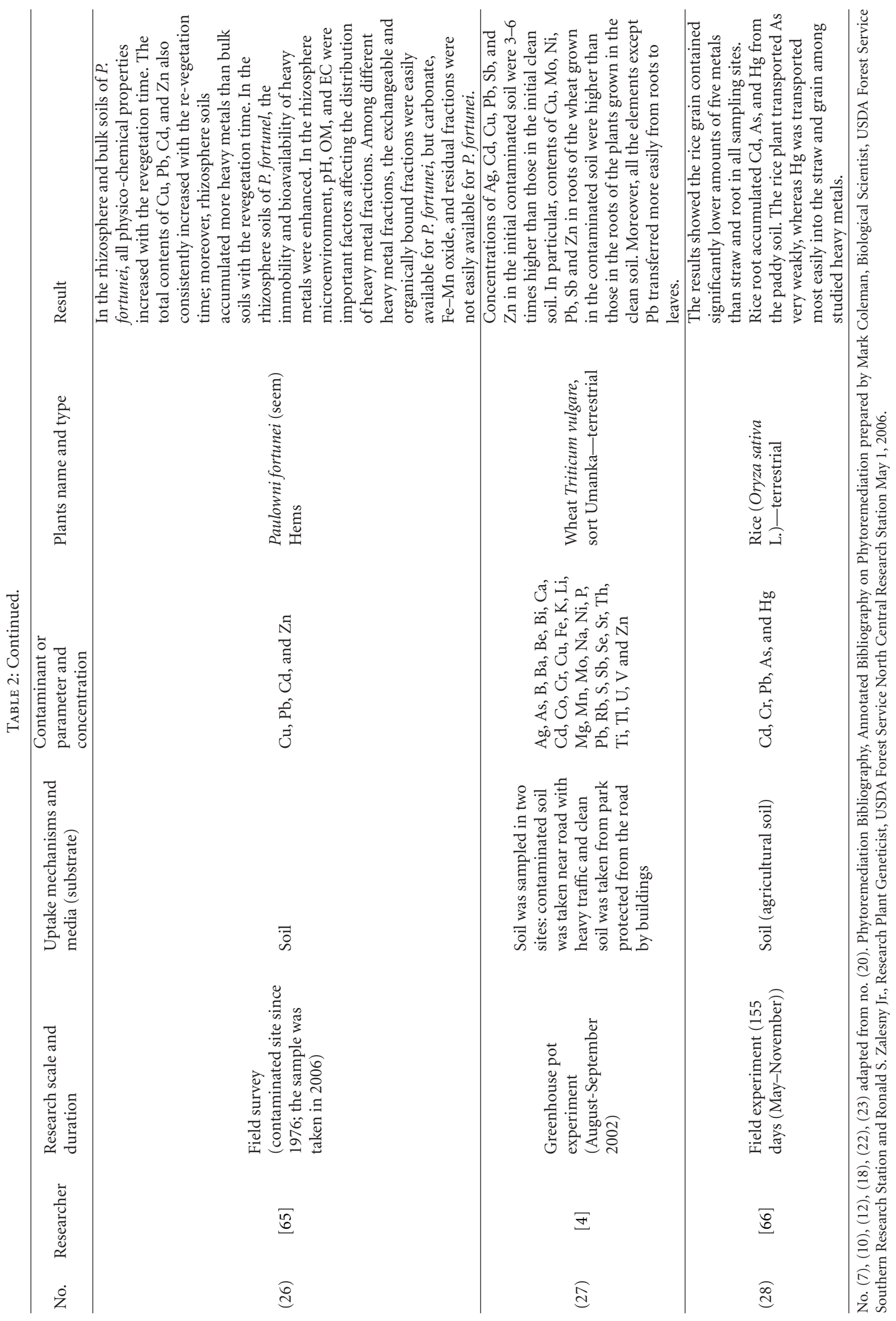




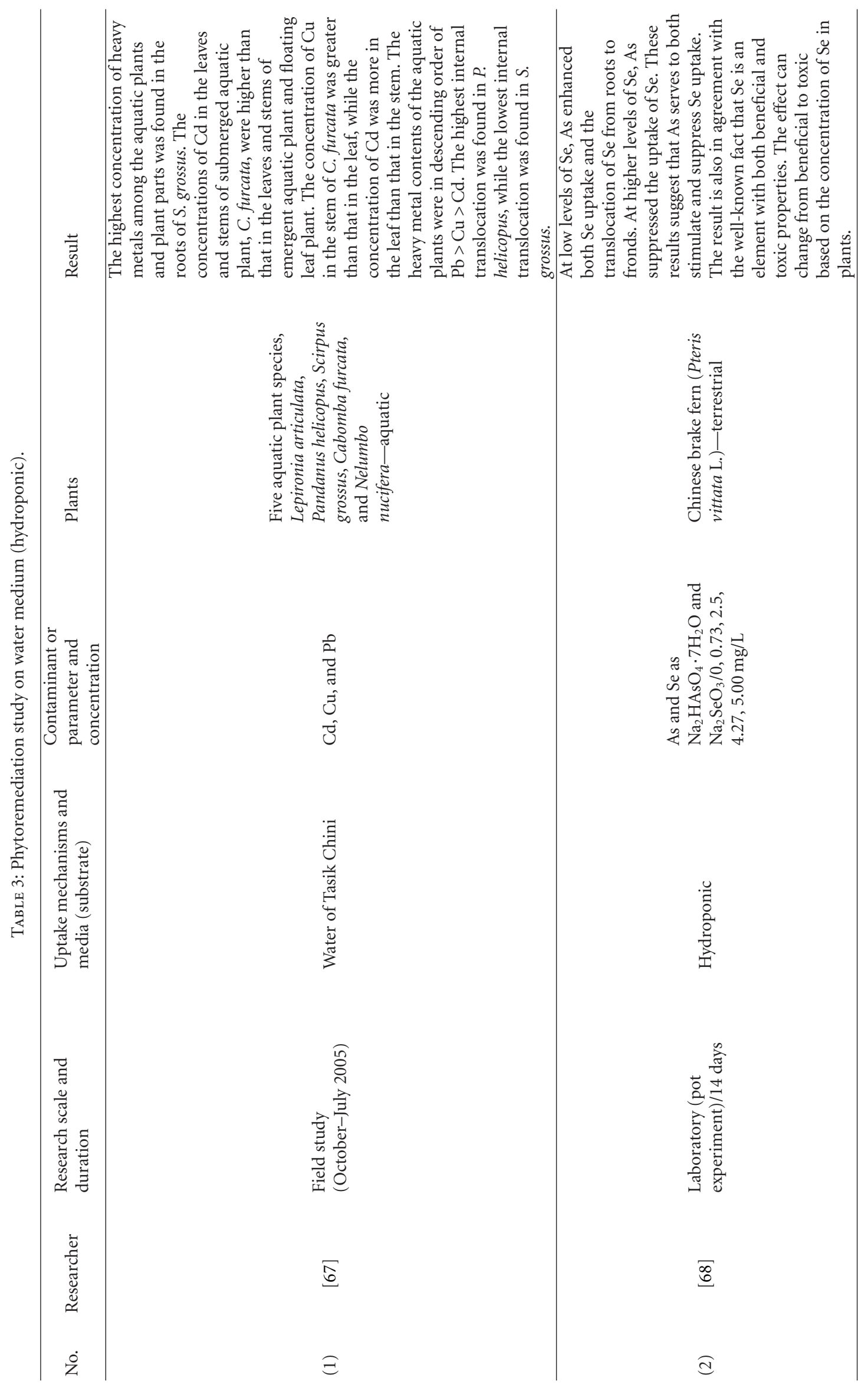




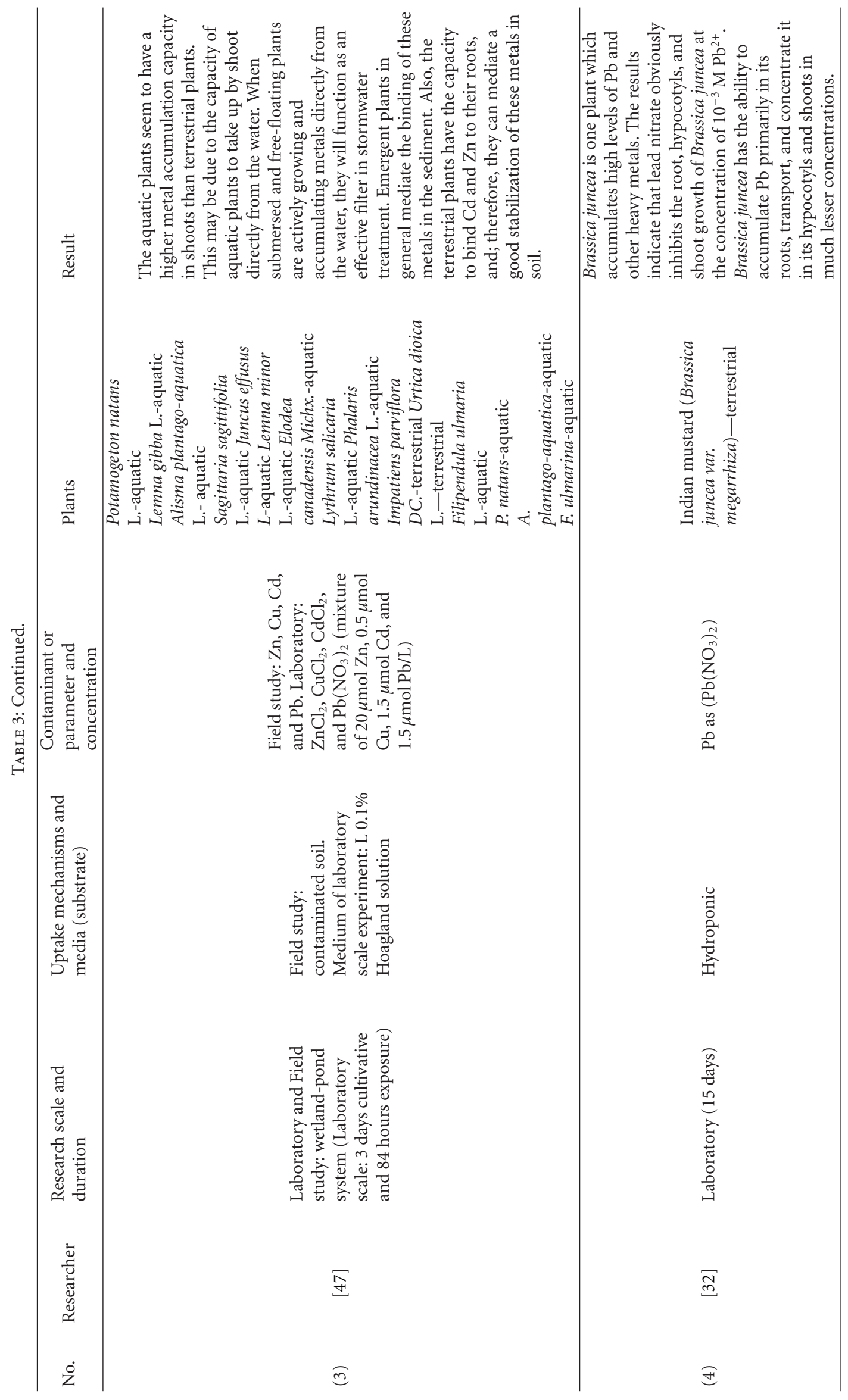




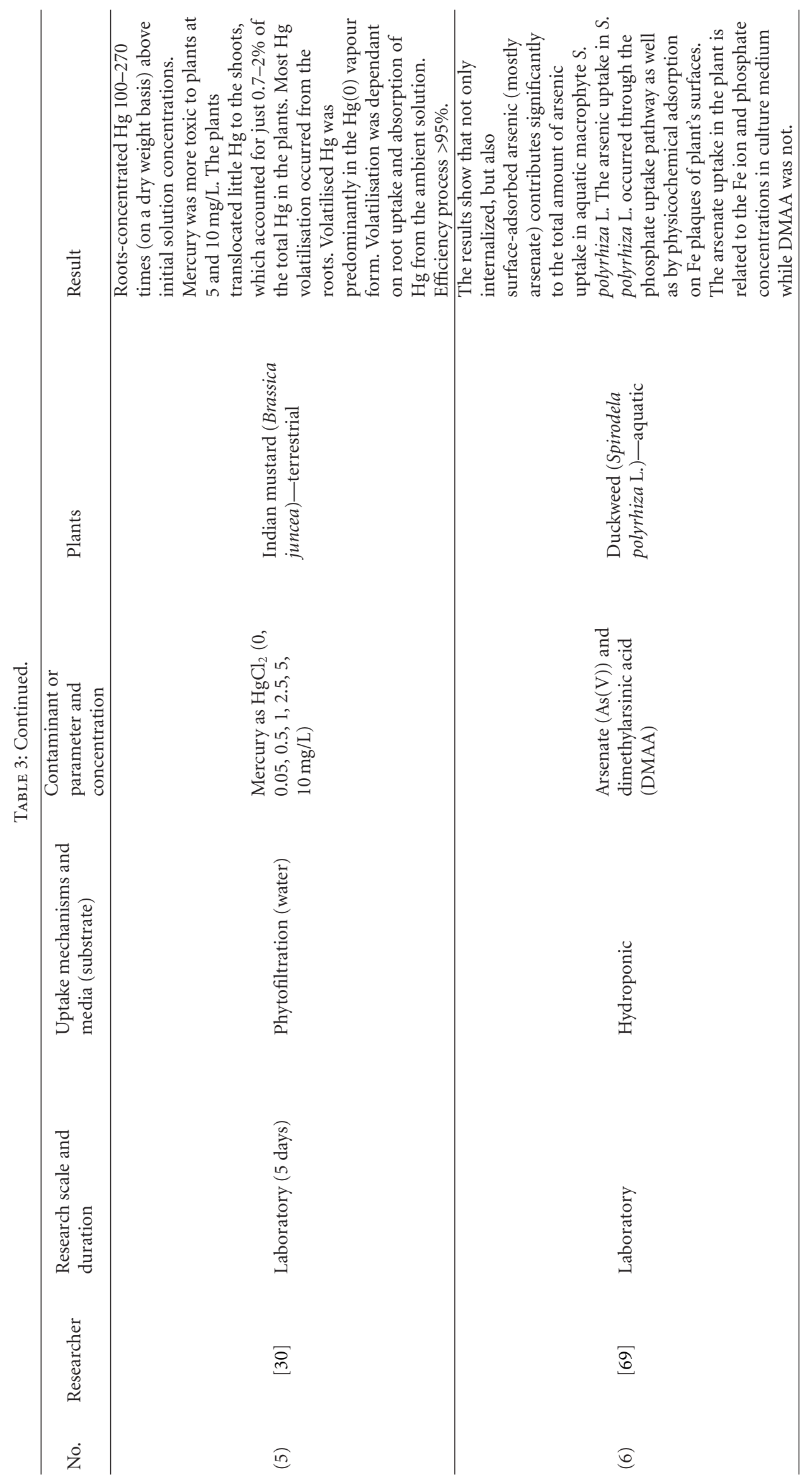




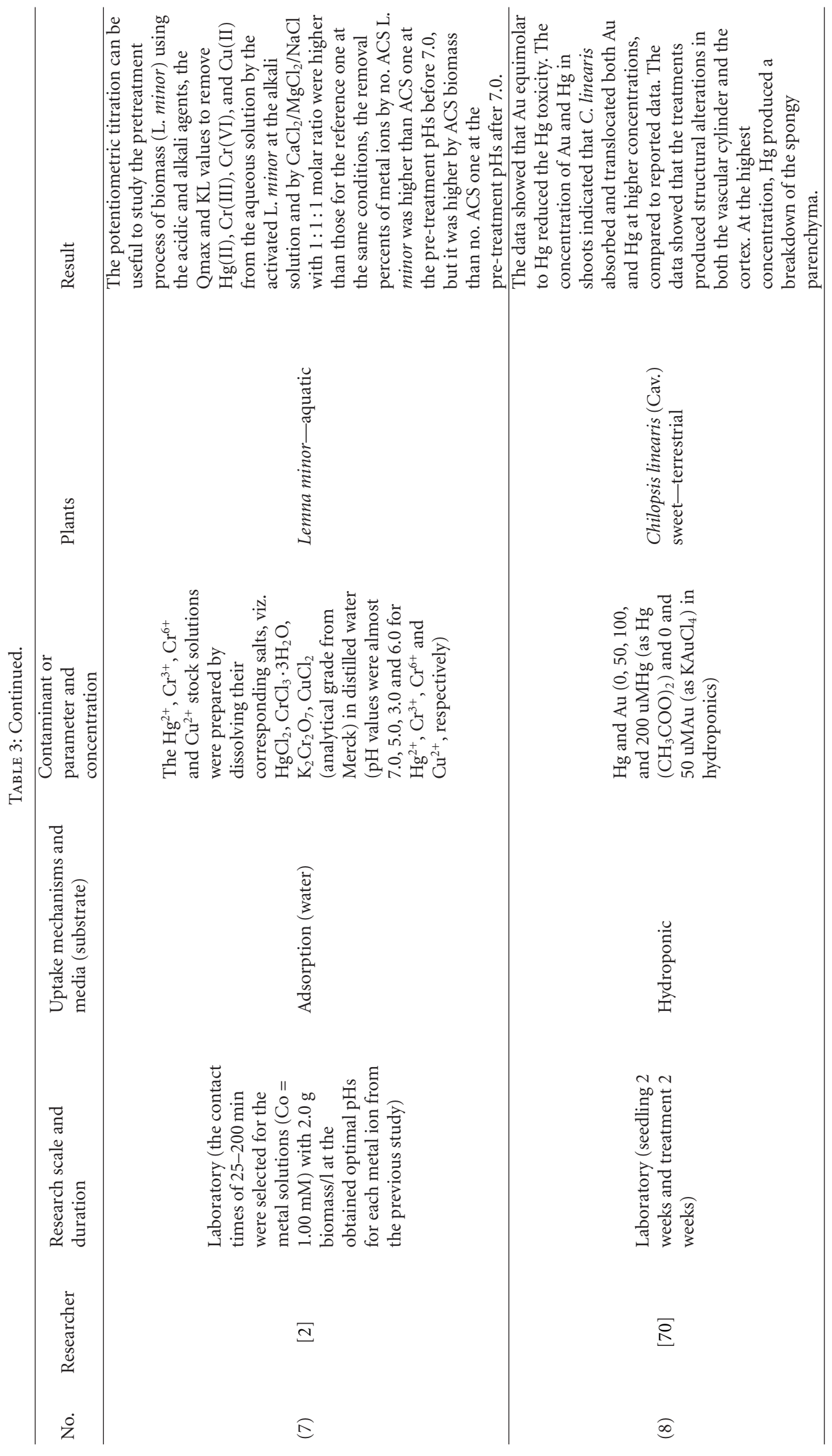




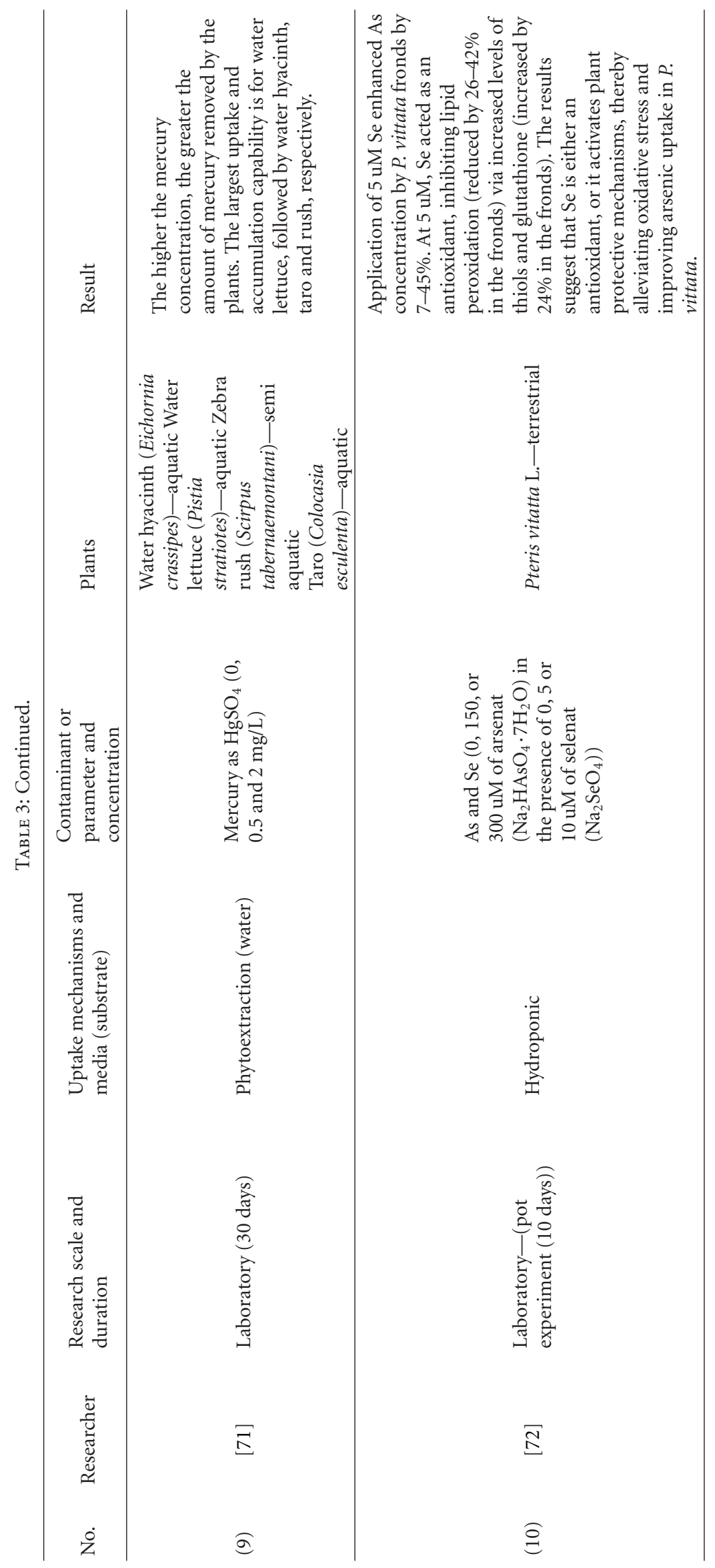




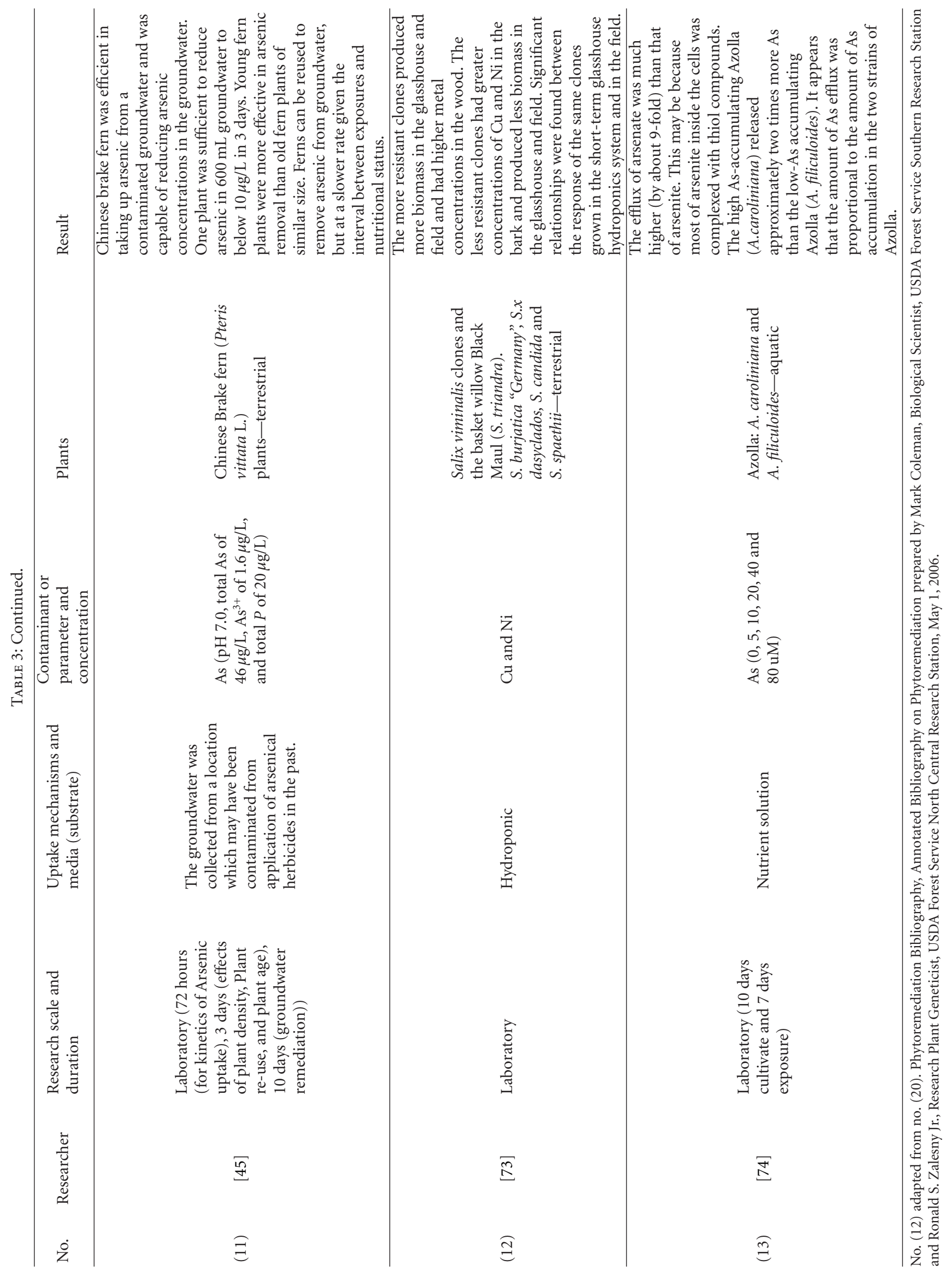




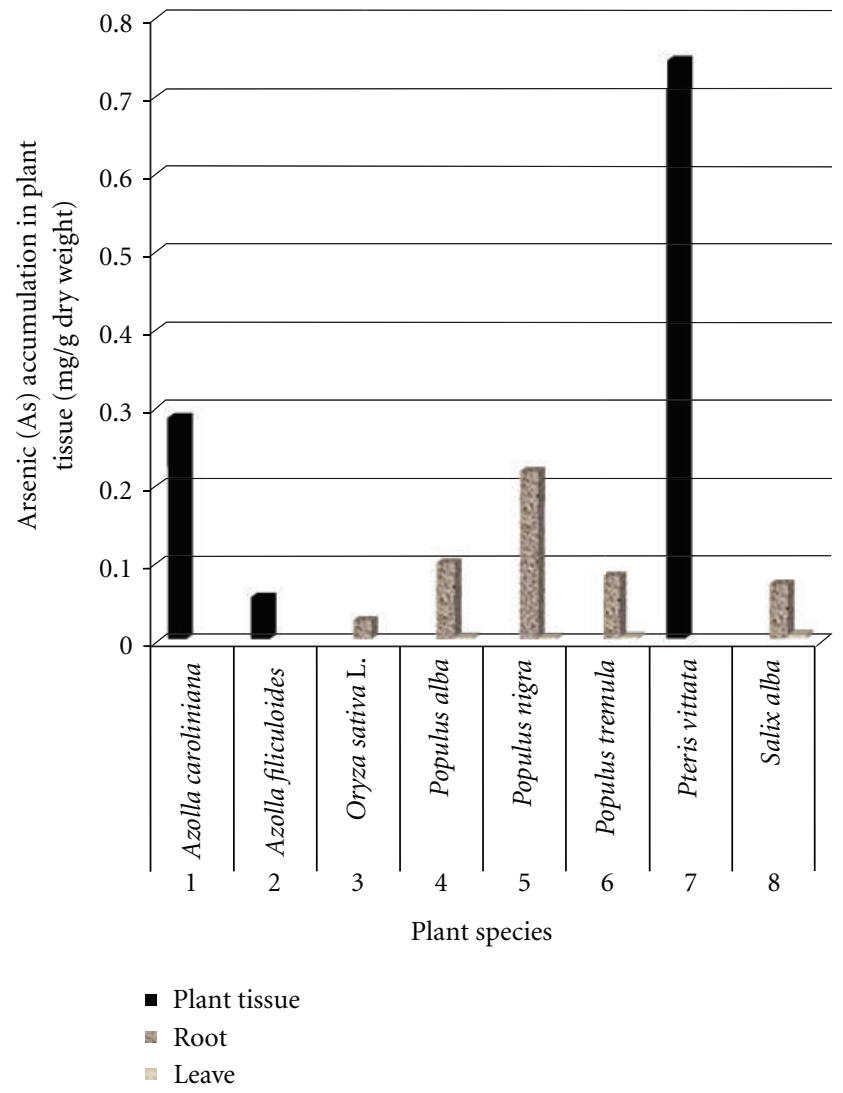

Figure 4: As accumulation in plant tissue.

Brassica nigra (L.) Koch that could accumulate more than $100 \mathrm{mg} \mathrm{Pb} / \mathrm{g}$ dry weight.

Figure 6 shows that accumulated $\mathrm{Hg}$ in Brassica juncea L. Czern. is much higher than in other species of plants. It could reach more than $1 \mathrm{mg} \mathrm{Hg} / \mathrm{g}$ dry weight of plant, while the other plants only accumulate less than $0.2 \mathrm{mg} \mathrm{Hg} / \mathrm{g}$ dry weight.

\section{Advantages of Phytoremediation}

Phytoremediation techniques may also be more publicly acceptable, aesthetically pleasing, and less disruptive than the current techniques of physical and chemical process [38]. Advantages of this technology are its effectiveness in contaminant reduction, low-cost, being applicable for wide range of contaminants, and in overall it is an environmental friendly method. Figure 7 simplifies some advantages of phytoremediation technology.

The major advantages of the heavy metal adsorption technology by biomass are its effectiveness in reducing the concentration of heavy metal ions to very low levels and the use of inexpensive biosorbent materials [2]. Phytoremediation as possibly the cleanest and cheapest technology can be employed in the remediation of selected hazardous sites [29]. Phytoremediation encompasses a number of different methods that can lead to contaminant degradation [24].

Phytoremediation is a low-cost option and inexpensive approach for remediating environmental media, particularly

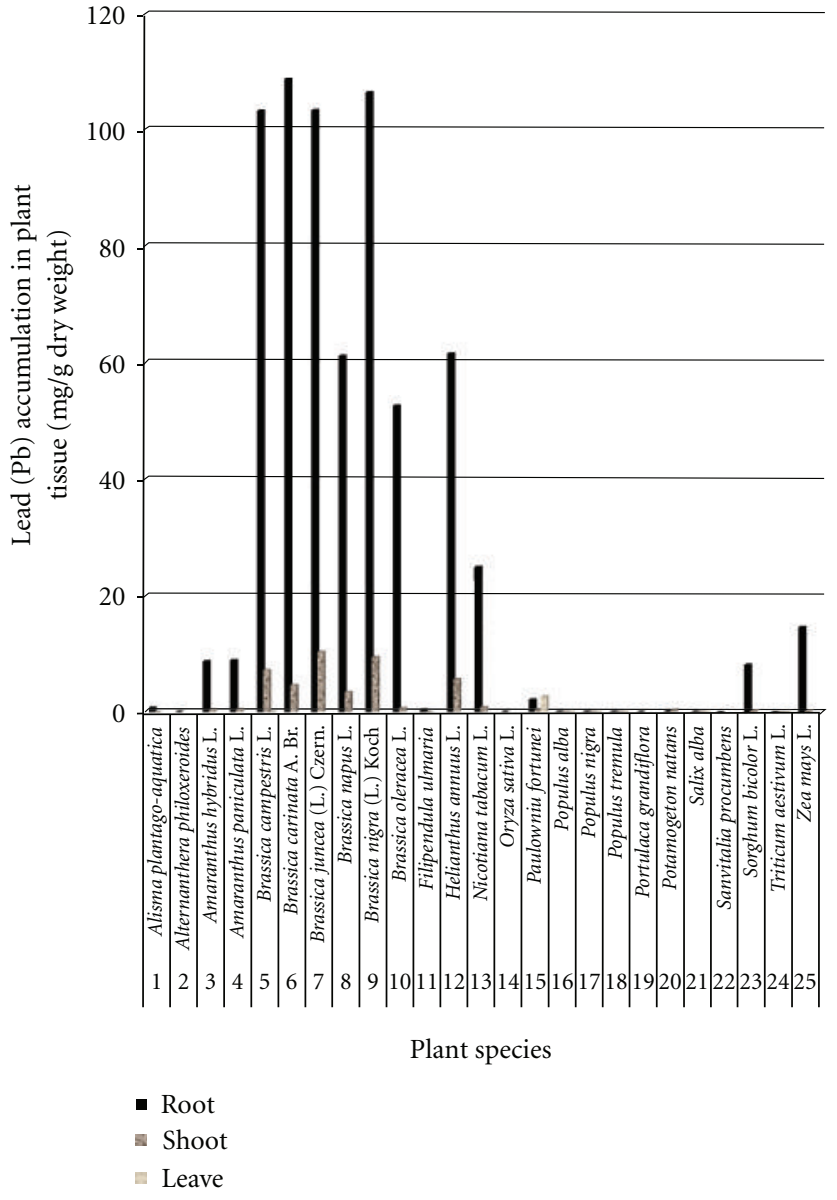

FIgURE 5: $\mathrm{Pb}$ accumulation in plant tissue.

suited to large sites that have relatively low levels of contamination [34]. This technology has been receiving attention lately as an innovative, cost-effective alternative to the more established treatment methods used at hazardous waste sites [29]. Phytoremediation potentially offers unique, low cost solutions to many currently problems of soil contamination $[32,75]$. It is inexpensive $(60-80 \%$ or even less costly) than conventional physicochemical methods, since it does not require expensive equipment or highly specialized personnel. It is cost-effective for large volumes of water having low concentrations of contaminants and for large areas having low to moderately contaminated surface soils [46].

It is applicable to a wide range of toxic metals and radionuclides [32] and also useful for treating a broad range of environmental contaminants, including organic and inorganic contaminants [46].

Phytoremediation is regarded as a new approach for the cleanup of contaminated soils, water, and ambient air [34]. Phytoremediation research can also contribute to the improvement of poor soils such as those with high aluminum or salt levels [75]. It is applicable to a range of toxic metals and radionuclides, minimal environmental disturbance, elimination of secondary air or water-borne wastes, and public acceptance [32]. Phytoextraction is considered as an environmentaly friendly method to remove metals from 


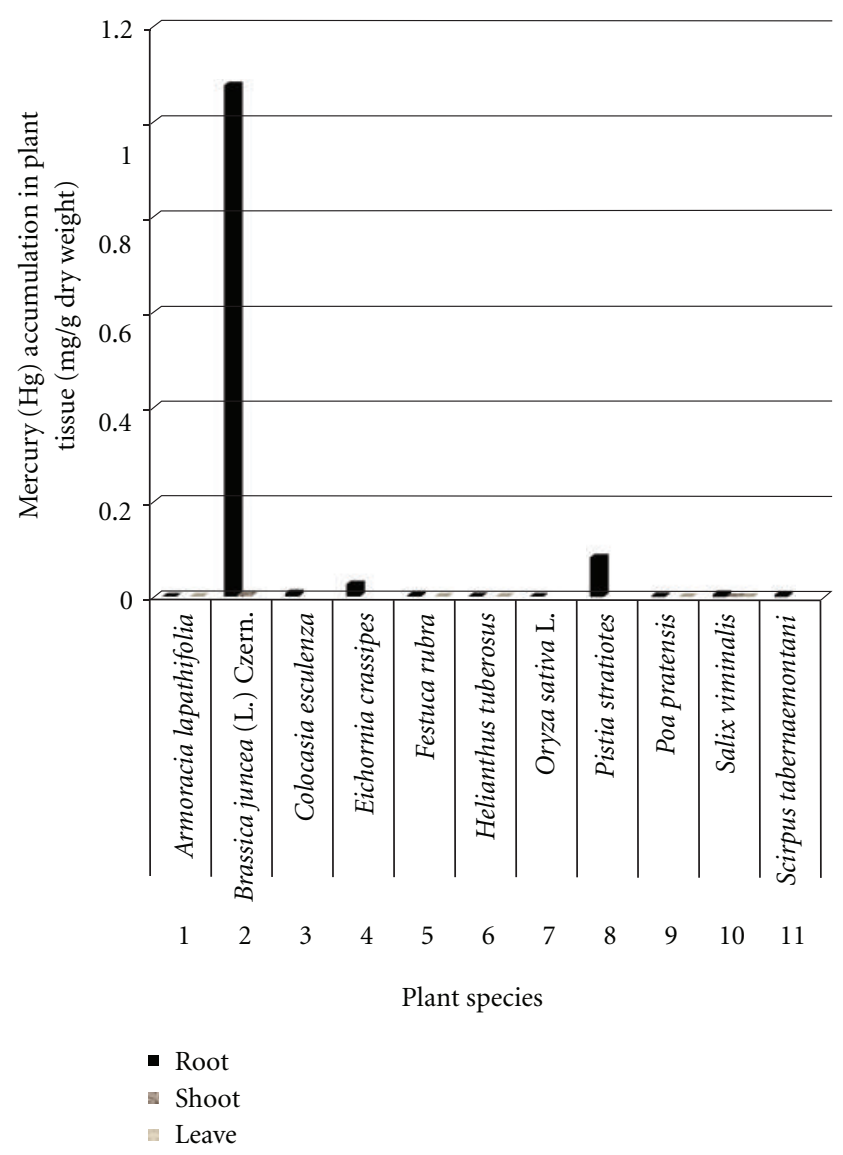

FIGURE 6: Hg accumulation in plant tissue.

contaminated soils in situ. This method can be used in much larger-scale clean-up operations and has been applied for other heavy metals [76]. It is an esthetically pleasing, solarenergy-driven cleanup technology and there is minimal environmental disruption and in situ treatment preserves topsoil. In Situ applications decrease the amount of soil disturbance compared to conventional methods. It can be performed with minimal environmental disturbance with topsoil left in a usable condition and may be reclaimed for agricultural use. The organic pollutants may be degraded to $\mathrm{CO}_{2}$ and $\mathrm{H}_{2} \mathrm{O}$, removing environmental toxicity [46]. Phytoremediation can be an alternative to the much harsher remediation technologies of incineration, thermal vaporization, solvent washing, or other soil washing techniques, which essentially destroy the biological component of the soil and can drastically alter its chemical and physical characteristics as well as creating a relatively nonviable solid waste. Phytoremediation actually benefits the soil, leaving an improved, functional soil ecosystem at costs estimated at approximately one-tenth of those currently adopted technologies [3]. It is the most ecological cleanup technology for contaminated soils and is also known as a green technology.

Another advantage of phytoremediation is the generation of a recyclable metal-rich plant residue [32]. Phytoremediation could be a viable option to decontaminate heavy-metal-polluted soils, particularly when the biomass produced during the phytoremediation process could be economically valorized in the form of bioenergy. The use of metal-accumulating bioenergy crops might be suitable for this purpose. If soils, contaminated with heavy metals, are phytoremediated with oil crops, biodiesel production from the resulting plant oil could be a viable option to generate bioenergy [34]. In large-scale applications, the potential energy stored can be utilized to generate thermal energy [46]. The success of the phytoextraction technique depends upon the identification of suitable plant species that can hyperaccumulate heavy metals and produce large amounts of biomass using established crop production and management practices [24].

\section{Limitations of Phytoremediation Technology}

On the other hand, there are certain limitations to phytoremediation system (Figure 8). Among them are being timeconsuming method, the amount of produced biomass, the root depth, soil chemistry and the level of contamination, the age of plant, the contaminant concentration, the impacts of contaminated vegetation, and climatic condition.

Phytoremediation can be a time-consuming process, and it may take at least several growing seasons to clean up a site. The intermediates formed from those organic and inorganic contaminants may be cytotoxic to plants [46]. Phytoremediation is also limited by the growth rate of the plants. More time may be required to phytoremediate a site as compared with other more traditional cleanup technologies. Excavation and disposal or incineration takes weeks to months to accomplish, while phytoextraction or degradation may need several years. Therefore, for sites that pose acute risks for human and other ecological receptors, phytoremediation may not be the remediation technique of choice $[29,46]$. Phytoremediation might be best suited for remote areas where human contact is limited or where soil contamination does not require an immediate response [38].

Under the best climatic conditions, with irrigation and fertilization, total biomass productivities can approach $100 \mathrm{t} / \mathrm{ha} / \mathrm{y}$. One of the unresolved issues is the tradeoff between toxic element accumulation and productivity. In practice, a maximum harvestable biomass yield of 10 to 20 t/ha/y would be likely, particularly for heavy metal accumulating plants. These values for productivity of biomass and heavy metal content would limit annual toxic element removal capacity between about 10 and $400 \mathrm{~kg} / \mathrm{ha} / \mathrm{y}$, depending on the pollutant, plant species, climatic and other factors. For a target soil depth of $30 \mathrm{~cm}(4,000 \mathrm{t} / \mathrm{ha})$, this amounts to an annual reduction from 2.5 to $100 \mathrm{ppm}$ in soil toxic element levels. This is often an acceptable rate of contaminant removal, allowing site remediation over a few years to a couple of decades, particularly where the concentration of the contaminant can be lowered sufficiently to meet regulatory criteria. These values for productivity of biomass and heavy metal content would limit annual toxic element removal capacity between 10 and $400 \mathrm{~kg} / \mathrm{ha} / \mathrm{y}$, depending on the pollutant, plant species, climatic and other factors [37].

The success of phytoremediation may be limited by factors such as growing time, climate, root depth, soil 


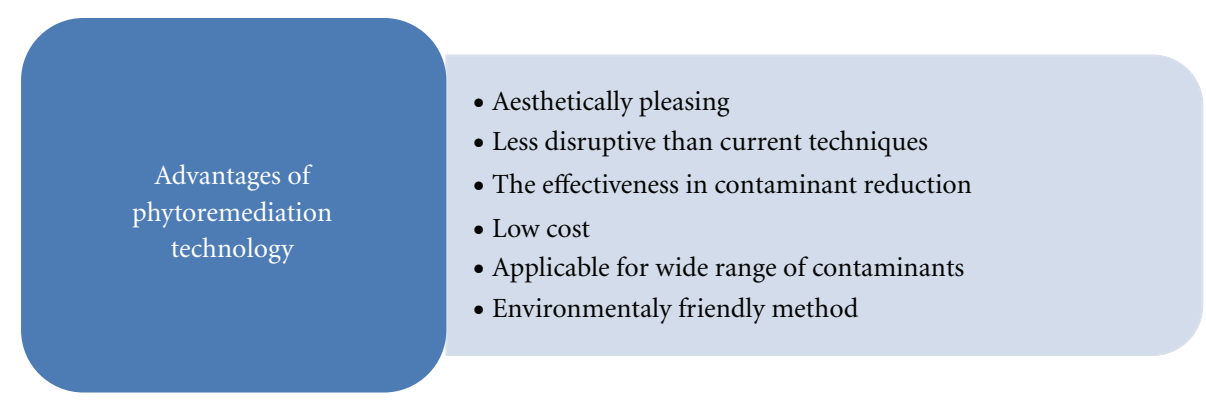

FIGURE 7: Advantages of phytoremediation technology.

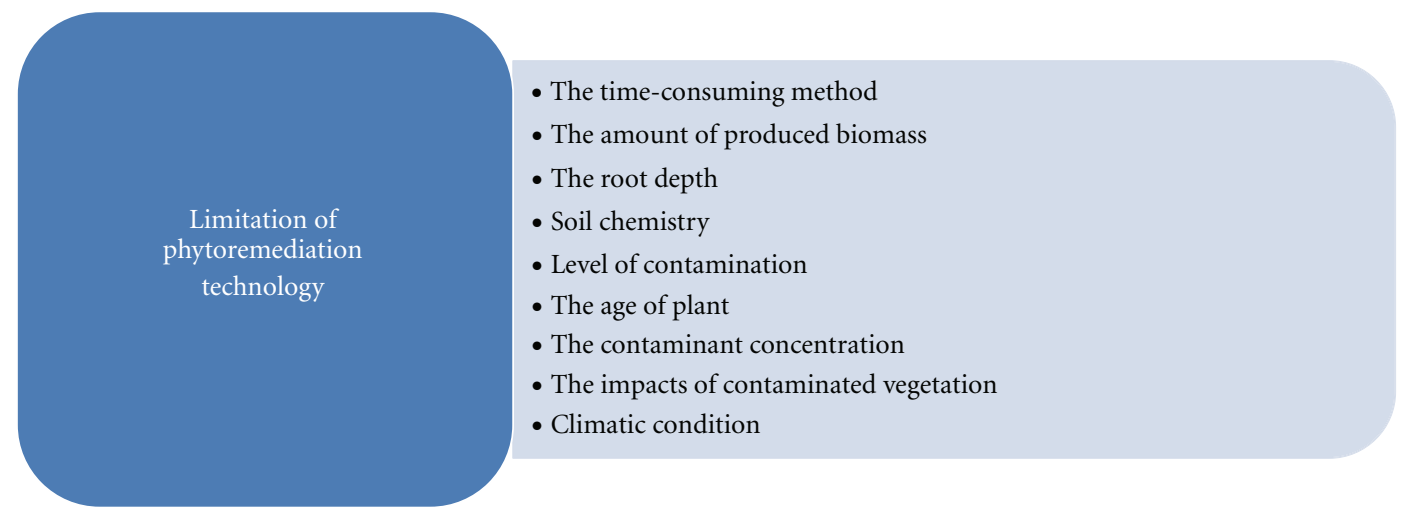

FIgURE 8: The limitation of phytoremediation technology.

chemistry, and level of contamination [38]. Root contact is a primary limitation on phytoremediation applicability. Remediation with plants requires that contaminants be in contact with the root zone of the plants. Either the plants must be able to extend roots to the contaminants, or the contaminated media must be moved to be within range of the plants [29]. Restricted to sites with shallow contamination within rooting zone of remediative plants, ground surface at the site may have to be modified to prevent flooding or erosion [46].

Age greatly affects the physiological activity of a plant, especially its roots. Generally, roots of a young plant display greater ability to absorb ions than do those of an old plant when they are similar in size. It is important to use healthy young plants for more efficient plant removal. However, this does not rule out the use of larger older plants whose larger size may compensate for their lower physiological activity as compared to smaller younger plants [45].

High concentrations of contaminants may inhibit plant growth and, thus, may limit application on some sites or some parts of sites. This phytotoxicity could lead to a remedial approach in which high-concentration waste is handled with expensive ex situ techniques that quickly reduce acute risk, while in situ phytoremediation is used over a longer period of time to clean the high volumes of lower contaminant concentrations [29]. A major limitation in the phytoremediation of toxic elements is the maximal level that can be accumulated by plants. Plants with the highest levels of toxic metal contents, known as "hyperaccumulators", generally exhibit, on a dry weight basis, from about $2000 \mathrm{ppm}(0.2 \%)$ for more toxic elements $(\mathrm{Cd}, \mathrm{Pb})$ to above $2 \%$ for the less toxic ones ( $\mathrm{Zn}, \mathrm{Ni}, \mathrm{Cu}$ ) [75]. Restricted to sites with low contaminant concentrations, the treatment is generally limited to soils at one meter from the surface and groundwater within a few meters of the surface with soil amendments may be required [46].

Some ecological exposure may occur whenever plants are used to interact with contaminants from the soil. The fate of the metals in the biomass is a concern. Although some forms of phytoremediation involve accumulation of metals and require handling of plant material embedded with metals, most plants do not accumulate significant levels of organic contaminants. While metal-accumulating plants will need to be harvested and either recycled or disposed of in compliance with applicable regulations, most phytoremediative plants do not require further treatment or disposal [29]. Harvested plant biomass from phytoextraction may be classified as a hazardous waste, hence, disposal should be proper. Consumption of contaminated plant biomass is a cause of concern; contaminants may still enter the food chain through animals/insects that eat plant material containing contaminants [46].

Climatic or hydrologic conditions may restrict the rate of growth of plants that can be utilized. Introduction of nonnative species may affect biodiversity [46]. 


\section{Conclusions}

Heavy metals uptake, by plants using phytoremediation technology, seems to be a prosperous way to remediate heavymetals-contaminated environment. It has some advantages compared with other commonly used conventional technologies. Several factors must be considered in order to accomplish a high performance of remediation result. The most important factor is a suitable plant species which can be used to uptake the contaminant. Even the phytoremediation technique seems to be one of the best alternative, it also has some limitations. Prolong research needs to be conducted to minimize this limitation in order to apply this technique effectively.

\section{References}

[1] A. Gaur and A. Adholeya, "Prospects of arbuscular mycorrhizal fungi in phytoremediation of heavy metal contaminated soils," Current Science, vol. 86, no. 4, pp. 528-534, 2004.

[2] R. Rakhshaee, M. Giahi, and A. Pourahmad, "Studying effect of cell wall's carboxyl-carboxylate ratio change of Lemna minor to remove heavy metals from aqueous solution," Journal of Hazardous Materials, vol. 163, no. 1, pp. 165-173, 2009.

[3] R. R. Hinchman, M. C. Negri, and E. G. Gatliff, "Phytoremediation: using green plants to clean up contaminated soil, groundwater, and wastewater," Argonne National Laboratory Hinchman, Applied Natural Sciences, Inc, 1995, http://www .treemediation.com/Technical/Phytoremediation_1998.pdf.

[4] I. Shtangeeva, J. V.-P. Laiho, H. Kahelin, and G. R. Gobran, " Phytoremediation of metal-contaminated soils. Symposia Papers Presented Before the Division of Environmental Chemistry," American Chemical Society, Anaheim, Calif, USA, 2004, http://ersdprojects.science.doe.gov/workshop_ pdfs/california_2004/p050.pdf.

[5] K. Cho-Ruk, J. Kurukote, P. Supprung, and S. Vetayasuporn, "Perennial plants in the phytoremediation of leadcontaminated soils," Biotechnology, vol. 5, no. 1, pp. 1-4, 2006.

[6] M. M. Lasat, "Phytoextraction of metals from contaminated soil: a review of plant/soil/metal interaction and assessment of pertinent agronomic issues," Journal of Hazardous Substance Research, vol. 2, no. 5, pp. 1-25, 2000.

[7] E. Pehlivan, A. M. Özkan, S. Dinç, and S. Parlayici, "Adsorption of $\mathrm{Cu}_{2+}$ and $\mathrm{Pb}_{2+}$ ion on dolomite powder," Journal of Hazardous Materials, vol. 167, no. 1-3, pp. 1044-1049, 2009.

[8] S. Roy, S. Labelle, P. Mehta et al., "Phytoremediation of heavy metal and PAH-contaminated brownfield sites," Plant and Soil, vol. 272, no. 1-2, pp. 277-290, 2005.

[9] D. Mohan and C. U. Pittman Jr., "Arsenic removal from water/wastewater using adsorbents - a critical review," Journal of Hazardous Materials, vol. 142, no. 1-2, pp. 1-53, 2007.

[10] National Ground Water Association, Copyright 2001. Arsenic. What you need to know http://www.ngwa.org/ASSETS/ A0DD107452D74B33AE9D5114EE6647ED/Arsenic.pdf.

[11] U.S. Department of Health and Human Services, Public Health Service Agency for Toxic Substances and Disease Registry. Division of Toxicology and Environmental Medicine. Arsenic. 2005, http://www.baltimorehealth.org/ info/ATSDR\%20fact\%20sheet.pdf.

[12] H. Hasegawa, M. A. Rahman, T. Matsuda, T. Kitahara, T. Maki, and K. Ueda, "Effect of eutrophication on the distribution of arsenic species in eutrophic and mesotrophic lakes," Science of the Total Environment, vol. 407, no. 4, pp. 1418-1425, 2009.

[13] WHO Regional Office for Europe, Air Quality Guidelines, chapter 6.1, Arsenic, Copenhagen, Denmark, 2nd edition, 2000, http://www.euro.who.int/document/aiq/6_1_ arsenic.pdf.

[14] P. Chutia, S. Kato, T. Kojima, and S. Satokawa, "Arsenic adsorption from aqueous solution on synthetic zeolites," Journal of Hazardous Materials, vol. 162, no. 1, pp. 440-447, 2009.

[15] H. A. Andrianisa, A. Ito, A. Sasaki, J. Aizawa, and T. Umita, "Biotransformation of arsenic species by activated sludge and removal of bio-oxidised arsenate from wastewater by coagulation with ferric chloride," Water Research, vol. 42, no. 19, pp. 4809-4817, 2008.

[16] R. J. Ampiah-Bonney, J. F. Tyson, and G. R. Lanza, "Phytoextraction of arsenic from soil by Leersia oryzoides," International Journal of Phytoremediation, vol. 9, no. 1, pp. 31-40, 2007.

[17] M. Vaclavikova, G. P. Gallios, S. Hredzak, and S. Jakabsky, "Removal of arsenic from water streams: an overview of available techniques," Clean Technologies and Environmental Policy, vol. 10, no. 1, pp. 89-95, 2008.

[18] A. M. Yusof and N. A. N. N. Malek, "Removal of Cr(VI) and As $(V)$ from aqueous solutions by HDTMA-modified zeolite Y," Journal of Hazardous Materials, vol. 162, no. 2-3, pp. 10191024, 2009.

[19] WHO Regional Office for Europe, Air Quality Guidelines, chapter 6.7, Lead, Copenhagen, Denmark, 2nd edition, 2001, http://www.euro.who.int/document/aiq/6_7lead.pdf.

[20] J. H. Traunfeld and D. L. Clement, "Lead in Garden Soils. Home and Garden," Maryland Cooperative Extention, University of Maryland, 2001, http://www.hgic.umd .edu/_media/documents/hg18.pdf.

[21] European Commission DG ENV. E3. Heavy Metals in Waste, Final Report Project ENV.E.3/ETU/2000/0058, 2002, http://ec .europa.eu/environment/waste/studies/pdf/heavy_metalsreport.pdf.

[22] J. F. Musselman and QEP, "Sources of Mercury in Wastewater, Pretreatment corner," http://www.cet-inc.com/ cmsdocuments//7\%20-\%20Sources\%20of\%20in\%20Wastewater\%20(0204).pdf.

[23] T. C. Chang, S. J. You, B. S. Yu, C. M. Chen, and Y. C. Chiu, "Treating high-mercury-containing lamps using fullscale thermal desorption technology," Journal of Hazardous Materials, vol. 162, no. 2-3, pp. 967-972, 2009.

[24] L. Rodriguez, F. J. Lopez-Bellido, A. Carnicer, F. Recreo, A. Tallos, and J. M. Monteagudo, "Mercury recovery from soils by phytoremediation," in Book of Environmental Chemistry, pp. 197-204, Springer, Berlin, Germany, 2005.

[25] I. Wagner-Döbler, "Microbiological treatment of mercuryloaded waste water-the biological mercury-decontamination-system. German Research Centre for Biotechnology," http://www.gbf.de/mercury_remediation1/pdf-documents/ Information $\% 20$ leaflet.PDF.

[26] A. Resaee, J. Derayat, S. B. Mortazavi, Y. Yamini, and M. T. Jafarzadeh, "Removal of Mercury from chlor-alkali industry wastewater using Acetobacter xylinum cellulose," American Journal of Environmental Sciences, vol. 1, no. 2, pp. 102-105, 2005.

[27] A. Sas-Nowosielska, R. Galimska-Stypa, R. Kucharski, U. Zielonka, E. Małkowski, and L. Gray, "Remediation aspect of microbial changes of plant rhizosphere in mercury contaminated soil," Environmental Monitoring and Assessment, vol. 137, no. 1-3, pp. 101-109, 2008. 
[28] A. Erakhrumen and A. Agbontalor, "Review Phytoremediation: an environmentally sound technology for pollution prevention, control and remediation in developing countries," Educational Research and Review, vol. 2, no. 7, pp. 151-156, 2007.

[29] U. S. Environmental Protection Agency, "Introduction to Phytoremediation," National Risk Management Research Laboratory, EPA/600/R-99/107, 2000, http://www.clu-in.org/ download/remed/introphyto.pdf.

[30] F. N. Moreno, C. W. N. Anderson, R. B. Stewart, and B. H. Robinson, "Phytofiltration of mercury-contaminated water: volatilisation and plant-accumulation aspects," Environmental and Experimental Botany, vol. 62, no. 1, pp. 78-85, 2008.

[31] M. N. V. Prasad and H. M. De Oliveira Freitas, "Metal hyperaccumulation in plants-biodiversity prospecting forphytoremediation technology," Electronic Journal of Biotechnology, vol. 6, no. 3, pp. 110-146, 2003.

[32] D. Liu, W. Jiang, C. Liu, C. Xin, and W. Hou, "Uptake and accumulation of lead by roots, hypocotyls and shoots of Indian mustard [Brassica juncea (L.)]," Bioresource Technology, vol. 71, no. 3, pp. 273-277, 2000.

[33] T. Bhattacharya, D. K. Banerjee, and B. Gopal, "Heavy metal uptake by Scirpus littoralis Schrad. from fly ash dosed and metal spiked soils," Environmental Monitoring and Assessment, vol. 121, no. 1-3, pp. 363-380, 2006.

[34] L. Van Ginneken, E. Meers, R. Guisson et al., "Phytoremediation for heavy metal-contaminated soils combined with bioenergy production," Journal of Environmental Engineering and Landscape Management, vol. 15, no. 4, pp. 227-236, 2007.

[35] Interstate Technology and Regulatory Council, Phytotechnology Technical and Regulatory. Guidance and Decision Trees, 2009, http://www.itrcweb.org/guidancedocument .asp?TID=63.

[36] R. K. Sinha, S. Herat, and P. K. Tandon, "14 phytoremediation: role of plants in contaminated site management," in Book of Environmental Bioremediation Technologies, pp. 315-330, Springer, Berlin, Germany, 2004.

[37] U. S. Department of Energy, "Plume Focus Area, December. Mechanisms of plant uptake, translocation, and storage of toxic elements. Summary Report of a workshop on phytoremediation research needs," 1994, http://www.osti.gov/ bridge/purl.cover.jsp;jsessionid=D72C8DD9003DCF51984E E254A6ED8BCB?purl=/10109412-BckU4U/webviewable/.

[38] A. L. Salido, K. L. Hasty, J. M. Lim, and D. J. Butcher, "Phytoremediation of arsenic and lead in contaminated soil using Chinese Brake ferns (Pteris vittata) and Indian mustard (Brassica juncea)," International Journal of Phytoremediation, vol. 5, no. 2, pp. 89-103, 2003.

[39] L. Erdei, G. Mezôsi, I. Mécs, I. Vass, F. Fôglein, and L. Bulik, "Phytoremediation as a program for decontamination of heavy-metal polluted environment," in Proceedings of the 8th Hungarian Congress on Plant Physiology and the 6th Hungarian Conference on Photosynthesis, 2005.

[40] L. Erdei, G. Mezôsi, I. Mécs, I. Vass, F. Fôglein, and L. Bulik, "Phytoremediation as a program for decontamination of heavy-metal polluted environment," Acta Biologica Szegediensis, vol. 49, no. 1-2, pp. 75-76, 2005.

[41] U. S. Environmental Protection Agency, Use of Field-Scale Phytotechnology, for Chlorinated Solvents, Metals, Explosives, and Propellants, and Pesticides Phytotechnology Mechanisms. Solid Waste and Emergency Response (5102G), EPA 542-R05-002, 2005, http://www.clu-in.org/download/remed/542-r05-002.pdf.
[42] V. M. Ibeanusi, "Denise Antonia Grab In collaboration with Larry, Jensen Stephen Ostrodka-Environmental Protection Agency. Radionuclide Biological Remediation Resource Guide, U. S. Environmental Protection Agency," 2004, http://www.clu-in.org/download/remed/905b04001.pdf.

[43] N. Merkl, R. Schultze-Kraft, and C. Infante, "Phytoremediation in the tropics-influence of heavy crude oil on root morphological characteristics of graminoids," Environmental Pollution, vol. 138, no. 1, pp. 86-91, 2005.

[44] J. G. Burken and J. L. Schnoor, "Phytoremediation: plant uptake of atrazine and role of root exudates," Journal of Environmental Engineering, vol. 122, no. 11, pp. 958-963, 1996.

[45] S. Tu, L. Q. Ma, A. O. Fayiga, and E. J. Zillioux, "Phytoremediation of arsenic-contaminated groundwater by the arsenic hyperaccumulating fern Pteris vittata L," International Journal of Phytoremediation, vol. 6, no. 1, pp. 35-47, 2004.

[46] W. J. S. Mwegoha, "The use of phytoremediation technology for abatement soil and groundwater pollution in Tanzania: opportunities and challenges," Journal of Sustainable Development in Africa, vol. 10, no. 1, pp. 140-156, 2008.

[47] A. Fritioff and M. Greger, "Aquatic and Terrestrial Plant Species with Potential to Remove Heavy Metals from Stormwater," International Journal of Phytoremediation, vol. 5, no. 3, pp. 211-224, 2003.

[48] P. Seuntjens, B. Nowack, and R. Schulin, "Root-zone modeling of heavy metal uptake and leaching in the presence of organic ligands," Plant and Soil, vol. 265, no. 1-2, pp. 61-73, 2004.

[49] R. Chandra, R. N. Bharagava, S. Yadav, and D. Mohan, "Accumulation and distribution of toxic metals in wheat (Triticum aestivum L.) and Indian mustard (Brassica campestris L.) irrigated with distillery and tannery effluents," Journal of Hazardous Materials, vol. 162, no. 2-3, pp. 1514-1521, 2009.

[50] M. Gupta, P. Sharma, N. B. Sarin, and A. K. Sinha, "Differential response of arsenic stress in two varieties of Brassica juncea L," Chemosphere, vol. 74, no. 9, pp. 1201-1208, 2009.

[51] D. Hammer, A. Kayser, and C. Keller, "Phytoextraction of $\mathrm{Cd}$ and $\mathrm{Zn}$ with Salix viminalis in field trials," Soil Use and Management, vol. 19, no. 3, pp. 187-192, 2003.

[52] R. E. Hamon, P. E. Holm, S. E. Lorenz, S. P. McGrath, and T. H. Christensen, "Metal uptake by plants from sludge-amended soils: caution is required in the plateau interpretation," Plant and Soil, vol. 216, no. 1-2, pp. 53-64, 1999.

[53] M. S. Liphadzi, M. B. Kirkham, K. R. Mankin, and G. M. Paulsen, "EDTA-assisted heavy-metal uptake by poplar and sunflower grown at a long-term sewage-sludge farm," Plant and Soil, vol. 257, no. 1, pp. 171-182, 2003.

[54] A. Murányi and L. Ködöböcz, "Heavy metal uptake by plants in different phytoremediation treatments," in Proceedings of the 7th Alps-Adria Scientific Workshop, Stara Lesna, Slovakia, 2008, http://www.mokkka.hu/publications/0387.117_MOKKA_AM_LK.pdf.

[55] I. D. Pulford, D. Riddell-Black, and C. Stewart, "Heavy metal uptake by willow clones from sewage sludge-treated soil: the potential for phytoremediation," International Journal of Phytoremediation, vol. 4, no. 1, pp. 59-72, 2002.

[56] J. Rydlová and M. Vosátka, "Effect of Glomus intraradices isolated from PB-contaminated soil on PB uptake by Agrostis capillaris is changed by its cultivation in a metal-free substrate," Folia Geobotanica, vol. 38, no. 2, pp. 155-165, 2003.

[57] L. Sebastiani, F. Scebba, and R. Tognetti, "Heavy metal accumulation and growth responses in poplar clones Eridano (Populus deltoides $\mathrm{x}$ maximowiczii) and I-214 (P. x 
euramericana) exposed to industrial waste," Environmental and Experimental Botany, vol. 52, no. 1, pp. 79-88, 2004.

[58] S. Sharma, "Study on impact of heavy metal accumulation in Brachythecium populeum (Hedw.) B.S.G," Ecological Indicators, vol. 9, no. 4, pp. 807-811, 2009.

[59] T. Vamerali, M. Bandiera, L. Coletto, F. Zanetti, N. M. Dickinson, and G. Mosca, "Phytoremediation trials on metaland arsenic-contaminated pyrite wastes (Torviscosa, Italy)," Environmental Pollution, vol. 157, no. 3, pp. 887-894, 2009.

[60] T. Vamerali, M. Bandiera, L. Coletto, F. Zanetti, N. M. Dickinson, and G. Mosca, "Phytoremediation trials on metaland arsenic-contaminated pyrite wastes (Torviscosa, Italy)," Environmental Pollution, vol. 157, no. 3, pp. 887-894, 2009.

[61] B. Vandecasteele, E. Meers, P. Vervaeke, B. D. Vos, P. Quataert, and F. M. G. Tack, "Growth and trace metal accumulation of two Salix clones on sediment-derived soils with increasing contamination levels," Chemosphere, vol. 58, no. 8, pp. 9951002, 2005.

[62] P. Vervaeke, F. M. G. Tack, N. Lust, and M. Verloo, "Shortand longer-term effects of the willow root system on metal extractability in contaminated dredged sediment," Journal of Environmental Quality, vol. 33, no. 3, pp. 976-983, 2004.

[63] M. Vyslouzilova, P. Tlustos, J. Szakova, and D. Pavlikova, “As, $\mathrm{Cd}, \mathrm{Pb}$ and $\mathrm{Zn}$ uptake by Salix spp.clones grown in soil enrich by high load of this elements," Plant Soil Environment, vol. 49, no. 5, pp. 191-196, 2003.

[64] H. B. Wang, Z. H. Ye, W. S. Shu, W. C. Li, M. H. Wong, and C. Y. Lan, "Arsenic uptake and accumulation in fern species growing at arsenic-contaminated sites of Southern China: field surveys," International Journal of Phytoremediation, vol. 8, no. 1, pp. 1-11, 2006.

[65] J. Wang, C. B. Zhang, and Z. X. Jin, "The distribution and phytoavailability of heavy metal fractions in rhizosphere soils of Paulowniu fortunei (seem) Hems near a $\mathrm{Pb} / \mathrm{Zn}$ smelter in Guangdong, PR China," Geoderma, vol. 148, no. 3-4, pp. 299306, 2009.

[66] W.-X. Liu, L.-F. Shen, J.-W. Liu, Y.-W. Wang, and S.-R. Li, "Uptake of toxic heavy metals by rice (Oryza sativa L.) cultivated in the agricultural soil near Zhengzhou City, People's Republic of China," Bulletin of Environmental Contamination and Toxicology, vol. 79, no. 2, pp. 209-213, 2007.

[67] M. Ebrahimpour and I. Mushrifah, "Heavy metal concentrations $(\mathrm{Cd}, \mathrm{Cu}$ and $\mathrm{Pb})$ in five aquatic plant species in Tasik Chini, Malaysia," Environmental Geology, vol. 54, no. 4, pp. 689-698, 2008.

[68] R. Feng, C. Wei, S. Tu, and X. Sun, "Interactive effects of selenium and arsenic on their uptake by Pteris vittata L. under hydroponic conditions," Environmental and Experimental Botany, vol. 65, no. 2-3, pp. 363-368, 2009.

[69] M. A. Rahman, H. Hasegawa, K. Ueda, T. Maki, and M. M. Rahman, "Arsenic uptake by aquatic macrophyte Spirodela polyrhiza L.: interactions with phosphate and iron," Journal of Hazardous Materials, vol. 160, no. 2-3, pp. 356-361, 2008.

[70] E. Rodríguez, J. R. Peralta-Videa, M. Israr et al., "Effect of mercury and gold on growth, nutrient uptake, and anatomical changes in Chilopsis linearis," Environmental and Experimental Botany, vol. 65, no. 2-3, pp. 253-262, 2009.

[71] K. Skinner, N. Wright, and E. Porter-Goff, "Mercury uptake and accumulation by four species of aquatic plants," Environmental Pollution, vol. 145, no. 1, pp. 234-237, 2007.

[72] M. Srivastava, L. Q. Ma, B. Rathinasabapathi, and P. Srivastava, "Effects of selenium on arsenic uptake in arsenic hyperaccumulator Pteris vittata L," Bioresource Technology, vol. 100, no. 3, pp. 1115-1121, 2009.
[73] C. Watson, I. D. Pulford, and D. Riddell-Black, "Screening of willow species for resistance to heavy metals: comparison of performance in a hydroponics system and field trials," International Journal of Phytoremediation, vol. 5, no. 4, pp. 351-365, 2003.

[74] X. Zhang, A. J. Lin, F. J. Zhao, G. Z. Xu, G. L. Duan, and Y. G. Zhu, "Arsenic accumulation by the aquatic fern Azolla: comparison of arsenate uptake, speciation and efflux by $A$. caroliniana and A. filiculoides," Environmental Pollution, vol. 156, no. 3, pp. 1149-1155, 2008.

[75] US Department of Energy, "Plume Focus Area. Summary Report of a Workshop on Phytoremediation Research Needs, Office of Technology Development, Office of Environmental Management and Division of Energy Biosciences, Office of Basic Energy Sciences, Office of Energy Research," 1994, http//www.law.csuohio.edu/lawlibrary-oldsite/info_services/acquisitions/acq-0104.html.

[76] Y. Wang and M. Greger, "Use of iodide to enhance the phytoextraction of mercury-contaminated soil," Science of the Total Environment, vol. 368, no. 1, pp. 30-39, 2006. 

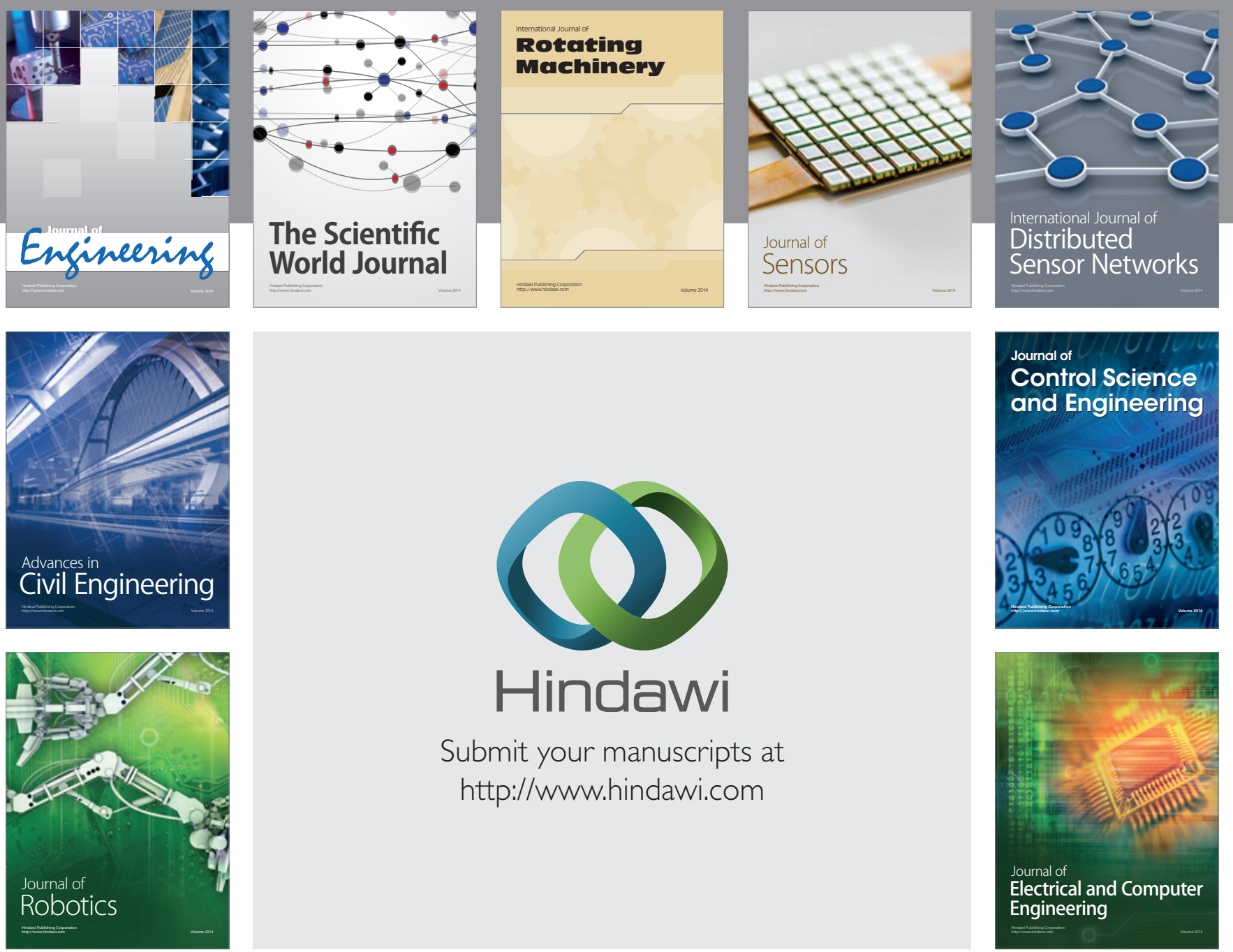

Submit your manuscripts at

http://www.hindawi.com
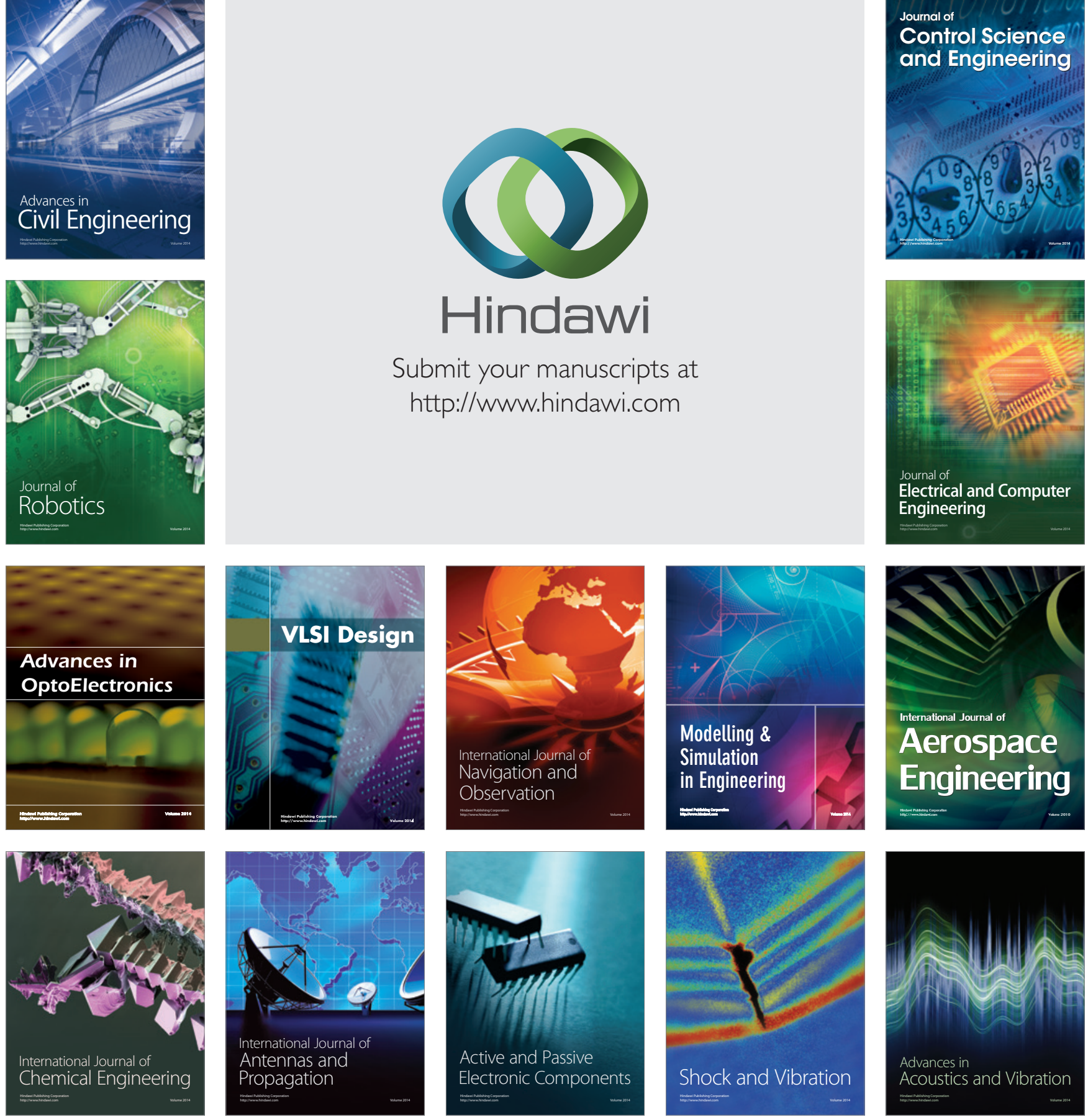